\title{
Competitive Exclusion of Cyanobacterial Species in the Great Salt Lake
}

Hillary Christine Roney

Brigham Young University - Provo

Follow this and additional works at: https://scholarsarchive.byu.edu/etd

Part of the Animal Sciences Commons

\section{BYU ScholarsArchive Citation}

Roney, Hillary Christine, "Competitive Exclusion of Cyanobacterial Species in the Great Salt Lake" (2008). Theses and Dissertations. 1826.

https://scholarsarchive.byu.edu/etd/1826

This Thesis is brought to you for free and open access by BYU ScholarsArchive. It has been accepted for inclusion in Theses and Dissertations by an authorized administrator of BYU ScholarsArchive. For more information, please contact scholarsarchive@byu.edu, ellen_amatangelo@byu.edu. 


\title{
Competitive Exclusion of Cyanobacterial Species in the Great Salt Lake
}

\author{
by \\ Hillary C. Roney \\ A thesis submitted to the faculty of \\ Brigham Young University \\ in partial fulfillment of the requirements for the degree of
}

Master of Science

Department of Plant and Wildlife Sciences

Brigham Young University

August 2008 
Copyright @ 2008 Hillary C. Roney

All Rights Reserved 


\section{BRIGHAM YOUNG UNIVERSITY}

\section{GRADUATE COMMITTEE APPROVAL}

of a thesis submitted by

Hillary C. Roney

This thesis has been read by each member of the following graduate committee and by majority vote has been found to be satisfactory.

Date

Date

Date

Date
Gary M. Booth, Chair

Donald P. Breakwell

John Gardner

Bruce Schaalje 


\section{BRIGHAM YOUNG UNIVERSITY}

As chair of the candidate's graduate committee, I have read the thesis of Hillary C.

Roney in its final form and have found that (1) its format, citations, and bibliographical style are consistent and acceptable and fulfill university and department style requirements; (2) its illustrative materials including figures, tables, and charts are in place; and (3) the final manuscript is satisfactory to the graduate committee and is ready for submission to the university library.

Date

Accepted for the Department

Date

Accepted for the College
Gary M. Booth

Chair, Graduate Committee
Loreen A. Woolstenhulme

Date

Rodney Brown 


\begin{abstract}
Competitive Exclusion of Cyanobacterial Species in the Great Salt Lake
\end{abstract}

\author{
Hillary C. Roney \\ Department of Plant and Wildlife Sciences \\ Master of Science
}

Under Gause's principle two species cannot indefinitely occupy the same niche. The north and south arms of Great Salt Lake are separated by a rail causeway, resulting in salinity differences and color variation between the arms. Farmington Bay is also separated from the south arm by a vehicular causeway to Antelope Island. These causeways allow examination of competitive exclusion of cyanobacteria in the hypersaline environment of the Great Salt Lake. Cyanobacterial distributions partially map salinity, with Aphanothece halophytica proliferating in the north arm, and Nodularia spumigena in the south arm. I hypothesized that cyanobacterial species abundant north of the railway causeway are competitively excluded from the south by other species, and that cyanobacterial species that thrive and bloom south of the Antelope Island causeway cannot grow in the high salinity of the north. To test these hypotheses, 129 flasks of autoclaved water from the north and south sides of each causeway were inoculated with Great Salt Lake water samples from the north and south sides of the causeways. Four 
cyanobacteria, Aphanothece, Oscillatoria, Phormidium, and Nodularia were identified and counted from the culture flasks using comparative differential interference contrast, fluorescence, and scanning electron microscopy. Counts of the cyanobacteria found in each flask were totaled and two way Analysis of Variance tests as well as exact tests were performed. Rankings of median abundances were also calculated.

These data support the first hypothesis because Aphanothece halophytica was found in all inocula, but appears to be suppressed by the presence of Nodularia spumigena, which periodically blooms. The second hypothesis is also supported by the data because $N$. spumigena was found only in inocula from the less saline waters south of Antelope Island causeway, and apparently cannot survive the high saline waters north of the railway causeway. 


\section{ACKNOWLEDGEMENTS}

I want to thank my advisor Dr. Booth and my graduate committee for all of their support, encouragement and help on this thesis. I thank the Institute for Ethnomedicine for access to their microscopy facility in Jackson Hole. I thank my parents, Paul and Barbara Cox, for contributing ideas, encouragement, transportation and support; my inlaws, Blake and Nancy Roney, for letting me use their greenhouse and encouragement; Professor Lee and the BYU Microbiology stockroom for autoclaving my samples; The BYU SEM lab for assistance on the ESEM; my husband Britton for pushing me forward and reading numerous drafts of this paper; and the countless brine shrimp that gave their lives for this research. 


\section{Table of Contents}

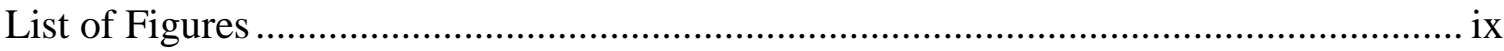

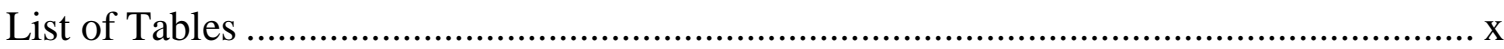

I. Introduction: Niches and Ecological Theory ....................................................... 1

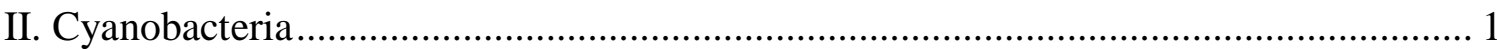

III. The Great Salt Lake and Causeway Partitioning ................................................... 4

IV. Previous Studies on the Cyanobacteria of the Great Salt Lake .................................. 7

V. Great Salt Lake Cyanobacteria and Gause's Principle ............................................. 9

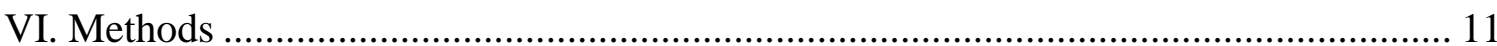

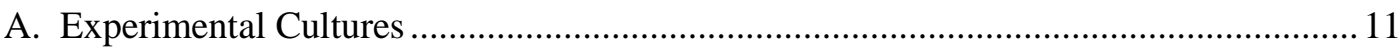

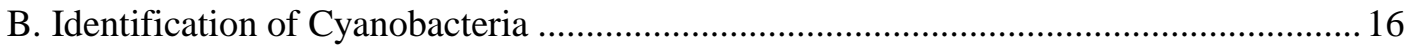

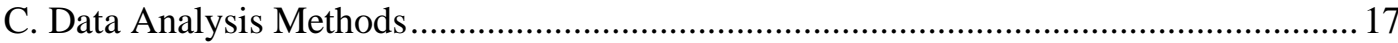

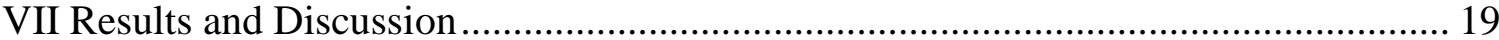

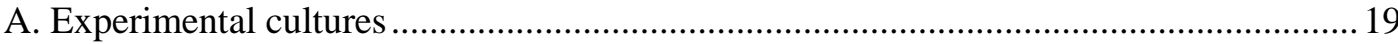

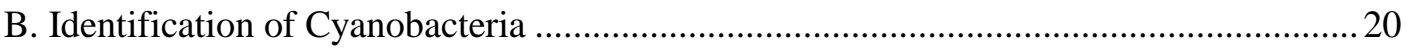

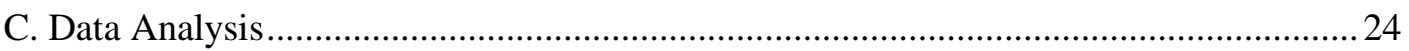

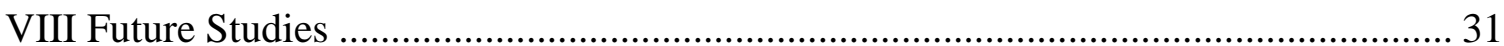

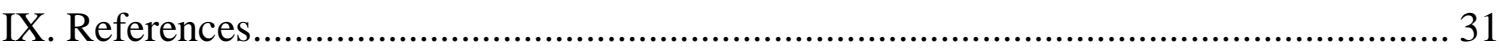

X. Appendix: Original and Transformed Data ............................................................ 35 


\section{List of Figures}

Figure 1: Union Pacific train on railway causeway ........................................... 4

Figure 2: The Great Salt Lake (From USGS) ..................................................... 5

Figure 3: North and south sides of the railway causeway. ................................... 9

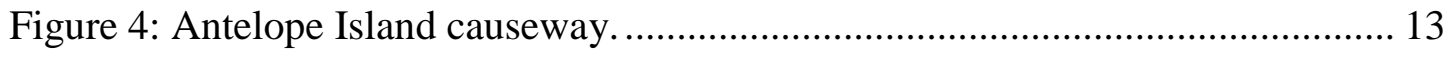

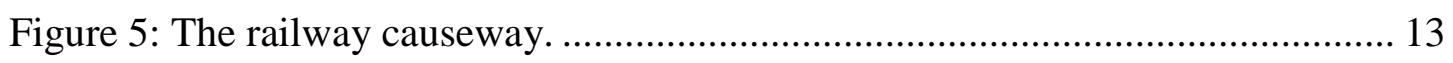

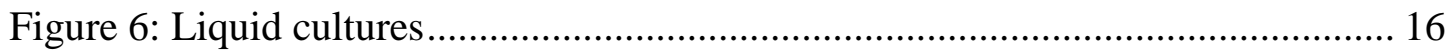

Figure 7: Samples from the north and south side of the railway causeway............... 19

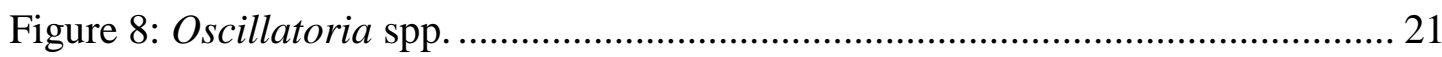

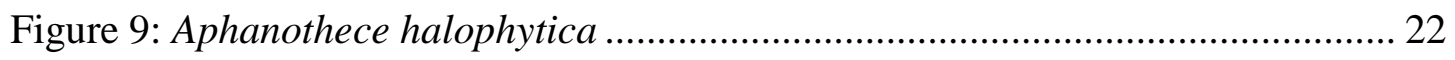

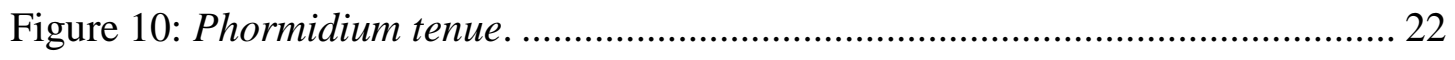

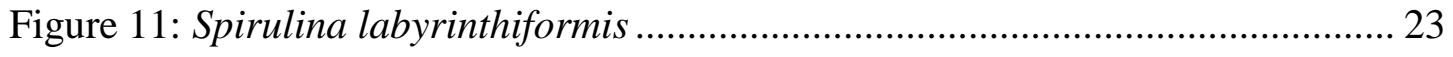

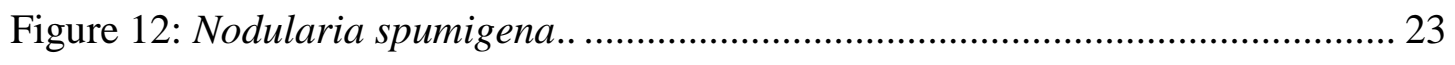

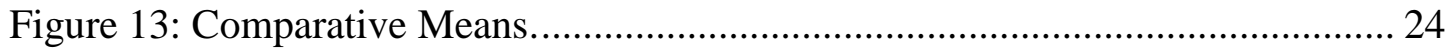




\section{List of Tables}

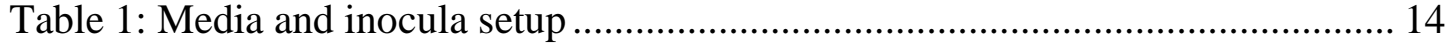

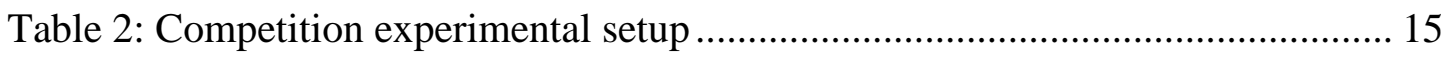

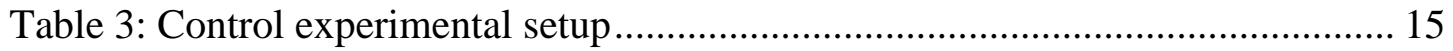

Table 4: Ranked orders of Aphanothece, Oscillatoria, Nodularia, and Phormidium. 25

Table 5: Cyanobacteria ranking by medians....................................................... 26

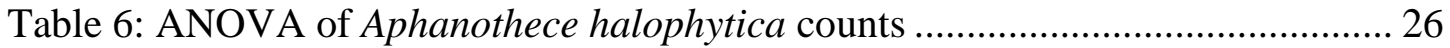

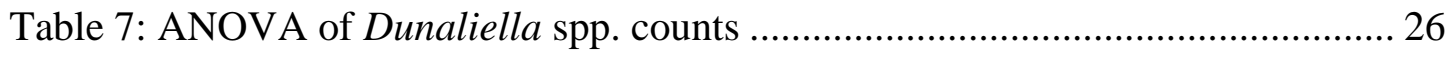




\section{Introduction: Niches and Ecological Theory}

In ecological theory, species occupy different niches within any given habitat. Niches, which can be mathematically represented as multi-dimensional volumes along axes of different nutrient, temperature, spatial, and biotic components, can be thought of as an organism's "profession". In a similar manner, the habitat can be thought of as an organisms "address." Often in constrained habitats, such as small oceanic atolls, a limited number of niches exist. This is reflected by the low terrestrial species diversity of atolls, as well as the high rates of extinction for new island immigrants. Niches are abundant in continental areas, such as tropical rainforests. Evolutionary forces, including adaptive radiation, can lead to species evolving specific niches. However, in ecological time, occupancy of niches occurs primarily through immigration and subsequent shifts in species distributions.

Although species diversity is greatest in areas with comparatively benign physical environments such as tropical rain forests or coral reefs, there is no theoretical reason why few species should exist in extreme environments such as arctic ice sheets, caves, undersea volcanic smokers, or hypersaline lakes unless limitations on species diversity in abiotically challenging environments likely reflect the limited ways that organisms can adapt to intense temperature, $\mathrm{pH}$, or osmotic stress.

\section{Cyanobacteria}

Cyanobacteria, once known as "blue-green" algae, are photosynthetic prokaryotic organisms that are perhaps most similar to the earliest organisms on earth than other extant species. Reliable fossil records suggest that cyanobacteria existed on earth approximately 3500 million years ago and are still very similar to their Precambrian 
microfossils (Castenholz 1992, Schopf 2000). Macrofossil indications of cyanobacterial presence consist of fossilized stromatolites, formed by layered secretions of cyanobacteria in marine systems.

Cyanobacteria are well-adapted for living in harsh conditions where other organisms cannot survive. Examples of such areas include deep sea thermal vents, photosynthetic areas beneath Antarctic ice, hot springs and geysers in Yellowstone, and high saline lakes and ponds, including the hypersaline environment of the Great Salt Lake (Dyer 2003).

Although cyanobacteria are taxonomically embedded within the Bacteria as a whole, phylogenetic relationships within the cyanobacterial radiation are not well understood (Brown et al. 2001). Genomes have been derived for Nostoc strains, but pending further genetic determination, relationships within the cyanobacterial radiation are unclear. Traditionally most workers split the cyanobacteria into five groups based on their branching morphology in culture (Rippka et al. 1979).

Since the cyanobacterial species are not well defined, and cyanobacteria taxonomy is poorly understood and often difficult to determine, different authors often use different names for the same morphological type (Oren 2000). This is true for the cyanobacterium Aphanothece halophytica. J. Bauld stated, “Aphanothece halophytica, Aphanocapsa halophytica, Aphanothece packardii, Polycystis packardii, Microcystis packardii, Aphanothece utahensis, and Coccochloris elabens, appear to be synonyms for the same coccoid cyanobacterium" (as quoted in Valera 1988a). The phenotypic method is still the most common and appropriate way of identifying and classifying cyanobacteria for practical purposes (Cronberg and Annadotter 2006). 
Two common cyanobacteria species that have been identified from the Great Salt Lake are Aphanothece halophytica and Nodularia spumigena. Thomas Brock was the first person to identify A. halophytica from the Great Salt Lake. Brock called $A$. halophytica, "the most halophilic blue-green alga known" (Brock 1976). Most of his isolates from the north part of the Lake were taken from a fossil algal reef just off Rozel Point in the northern arm. Brock found that A. halophytica grew the most rapidly in salt concentrations between 16-23\%, slow growth occurred at 7\%, no growth occurred at $3.5 \%$, and at $30 \%$ salt concentrations growth occurred but it was very slow (Brock 1976). A. halophytica is considered a true halophile and can be found worldwide at salinities above $100 \%$ (Oren 2000). The nomenclature of $A$. halophytica is confusing (as mentioned above) and very few, if any, modern taxonomic phylogenetic studies have been performed on Aphanothece. A. halophytica is unicellular varying from 2-10 $\mu \mathrm{m}$, has ellipsoidal, ovoid, or cylindrical shapes, and often has a mucilaginous polysaccharide coating. A. halophytica occurs both as a benthic and planktonic species (Oren 2000).

The cyanobacterium Nodularia spumigena is present in the most southern part of the Great Salt Lake (Farmington Bay). Sometimes there are large blooms of $N$. spumigena in Farmington Bay (Marcarelli et al. 2006). N. spumigena has a worldwide distribution and is a toxic species that produces the cyanotoxin nodularin. N. spumigena has straight or spirally twisted trichomes that are enclosed in a mucilaginous sheath and elliptical heterocysts which are $14 \mu \mathrm{m}$ in diameter and $7 \mu \mathrm{m}$ long (Cronberg and Annadotter 2006).

Since nitrogen is the limiting nutrient in the Great Salt Lake (Oren 2002) it is interesting to note that both A. halophytica and N. spumigena can fix nitrogen. $A$. 
halophytica fixes nitrogen and has the capability of anoxygenic photosynthesis with sulfide as an electron donor (Oren 2000).

\section{The Great Salt Lake and Causeway Partitioning}

The Great Salt Lake is a hypersaline, thalassohaline remnant of the ancient Pleistocene Lake Bonneville (Oren 2002b). About 15,000 years ago, Lake Bonneville was 346 miles $(557 \mathrm{~km})$ long and 145 miles $(233 \mathrm{~km})$ wide, occupying 20,000 square miles in what is now Utah, Idaho, and Nevada but then rapidly emptied due to a break in Red Rock pass in Idaho (Utah Geological Survey 1990). In prehistory, as Lake Bonneville retreated the lake lost all outlets, so salinity increased.

To save hundreds of additional rail miles for trains traveling across the North

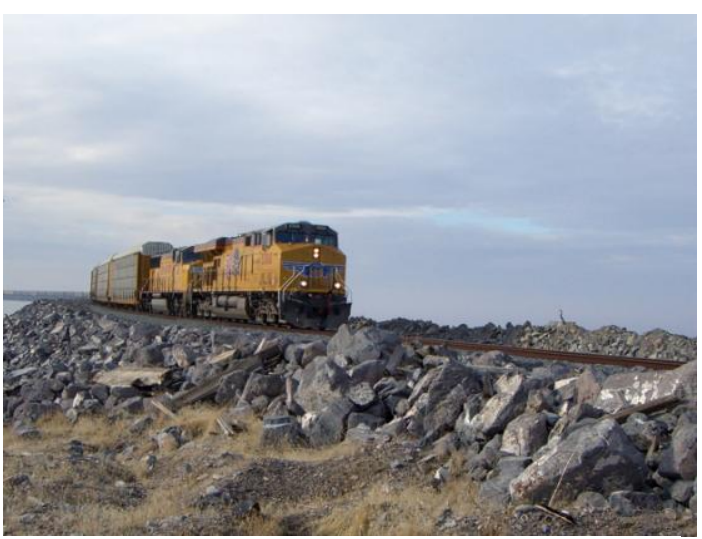

Figure 1: Union Pacific train on railway causeway
American continent, the Southern Pacific

Railroad (since absorbed into the Union

Pacific Railroad) constructed a railway causeway across the Great Salt Lake in 1959

(Fig. 1). This replaced an earlier trestle built in 1902 by Southern Pacific. To approach the former trestle, a rock fill crossed Bear River

Bay, and then led to an open wooden trestle (which did not impact flow of water) across the 12-13 mile central part of the lake (Butts 1980). The new 1959 central portion of the railway causeway is 12 miles $(19 \mathrm{~km})$ long and built with rock fill, with only two culverts allowing exchange of water between the north and south portions (Sturm 1980). The 1902 wooden trestle and the 1959 rock fill causeway routed trains directly across the lake waters, avoiding the historic terrestrial corridor which went north from Ogden near 
Promontory Point, where the golden spike was placed. Unlike the 1902 wooden trestle,

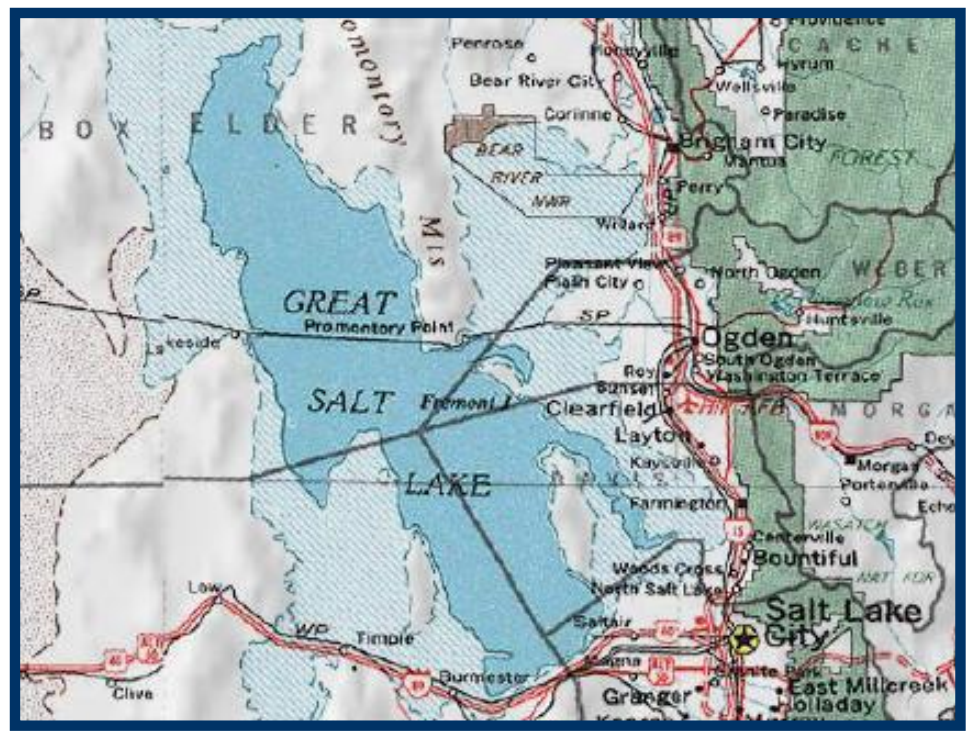

Figure 2: The Great Salt Lake (From USGS) the 1959 causeway

hydrologically divided the waters of the Great Salt Lake into two portions, a northern arm with negligible freshwater inputs, and a southern arm with more than $90 \%$ of the freshwater flow (Oren 2002b). Three major freshwater rivers

- the Bear River, the Weber River and the Jordan River - all flow into the Great Salt Lake south of the railway causeway (Gwynn 2002). The overall salinity of the Great Salt Lake, which to that point had been linked solely to changing lake levels, quickly adjusted with the northern arm becoming even more hypersaline, moving from an average of $15 \%$ in the 1870 s to as high as $28 \%$ salinity in the 1960 s (Sturm 1980). In 1970, the northern arm held approximately 330-350 g salts per liter, while the south arm held 120-130 g salts per liter (Oren 2002b).

The habitat changes, created by the construction of the railway causeway, were later partially replicated with construction of a second barrier to lake water flow - this time a causeway for vehicular use - from Syracuse, Utah to Antelope Island. Previously, a roadway was built over mud flats in about 1952 to the northern tip of Antelope Island, which was later turned into a highway in 1969 with the creation of Antelope Island State Park. Subsequent flooding in the early 1980s, concomitant with historic highs in the 
levels of the Great Salt Lake, breached the Antelope Island highway. After nearly a decade hiatus, the vehicular causeway was rebuilt in 1992 for visitor access to Antelope Island State Park (Gwynn 2002). These two different causeways resulted in the partitioning of the Great Salt Lake into three different salinity regimes: the northern arm, with an average of $27 \%$ salinity, the middle arm with average salinity of $10-16 \%$, and the southern arm, with average salinity of $6 \%$ or less (Utah Geological Survey 1990).

Geologically, the Great Salt Lake is divided into three bays: The northern part is called Gunnison Bay, the center part is called Gilbert Bay and the far southern part is called Farmington Bay (Fig 2). These three different salinity regimes, any one of which would be considered hypersaline, allowed species to sort according to ecological tolerances. The results are striking: each large area of the lake has different colored water, resulting in part from different concentrations of Artemia fransiscana brine shrimp cysts and microscopic green algae such as Dunaliella salina and Dunaliella viridis, but also perhaps due to different concentrations and species compositions of cyanobacteria.

By the early 1990s, three distinct hypersaline niches were inadvertently created in the Great Salt Lake by construction of the causeways. I became interested in seeing how cyanobacterial species sorted themselves in these varying salinity regimes and to see if biotic competition and salinity tolerances resulted in some cyanobacteria species being competitively excluded from some regions of the lake. I postulated that the partitioning of the lake by the two causeways could provide the basis for testing Gause's theory of competitive exclusion.

Previous explanations for apparent persistence of competing species in the same niche such as G. E. Hutchinson's 'Paradox of the Plankton' (1961), were based on the 
existence of non-equilibrium conditions, such as turbulence within the water column. Since the causeways across the Great Salt Lake were constructed decades ago, it is unlikely that cyanobacterial populations in the three different salinity regimes remain in disequilibrium due to turbulence or similar stochastic effects. Local turbulence generated by wave motion and storms may effect population dynamics within each salinity realm, but not between salinity realms. Hutchinson's "Paradox of the Plankton" does not, therefore, appear in the Great Salt Lake to allow persistence of cyanobacterial species which share the same niche. Darlington (1972) suggests that Hutchinson (1961) may have confused failure to achieve equilibrium with competitive exclusion. Therefore my experiments were designed to determine which cyanobacteria species occupy different regions, and to determine if any observed differences were due to an intrinsic difference in salt tolerance, or if they could be due to competitive exclusion.

\section{Previous Studies on the Cyanobacteria of the Great Salt Lake}

Since the Great Salt Lake in Utah is one of the largest saline lakes in the world (Sturm 1980), and because cyanobacteria are major factors in nitrogen cycles within the lake, its cyanobacterial flora is of significant interest. Prior to 1959 the Great Salt Lake was mostly uniform in its brine concentrations (Gywnn 2002). Now, with the railway and vehicular causeways, the waters are separated. In the vehicular causeway to Antelope Island, there are two 15 foot culverts that serve as the only connections between these parts of the lake that were once an uninterrupted body of water (Stephens and Gillespie 1976).

Felix and Rushforth (1980) identified four species of cyanobacteria that occur in the Great Salt Lake. They recorded Spirulina major as occurring only in Farmington Bay, 
and Coccochloris elebans as occurring only in the southern arm, with Microcoleus lyngbaceus and Nodularia spumigena occurring in both waters. These authors were apparently unaware of an earlier study by Brock (1976) in which he isolated the cyanobacterium Aphanothece halophytica from the Great Salt Lake. Felix (1978) may have observed this truly halophytic cyanobacterial species in the south arm but confused it with Coccochloris elebans (Felix and Rushforth 1980). Brock notes:

"This alga could be cultured from other samples collected in saturated brine which did not show any microscopic evidence of the organism ... Since cultures of the halophytic Aphanothece were able to grow in saturated brine, albeit very slow, it seems reasonable to conclude that the alga can maintain populations in brine, but grows much better when the salinity is reduced" (1976).

In their 1980 paper, Felix and Rushforth cite Flowers and Evans, (1966) who report Coccochloris elabens (Aphanothece halophytica) as the most abundant algal species in the lake. Felix and Rushforth's explanation for finding C. elebans infrequently was that the decreasing salinity in the south arm fosters diatom growth and limits the growth of C. elabens (Felix and Rushforth 1980). In 1982, Rushforth and Felix listed C. elabens as common in the south arm, with Nodularia spumigena as rare in the south arm.

In my initial sampling, I found clear visual differences in color on both sides of the railway causeway (Fig. 3) which perhaps reflects differences in cyanobacterial species composition in addition to Dunaliella densities. This raises an interesting ecological question: are the species on north side of the causeway and the species on the south side of the causeway uniquely adapted to high and low salinity respectively, or, could the northern species grow in the fresher southern waters, but are prevented from doing so by competition from other species? 


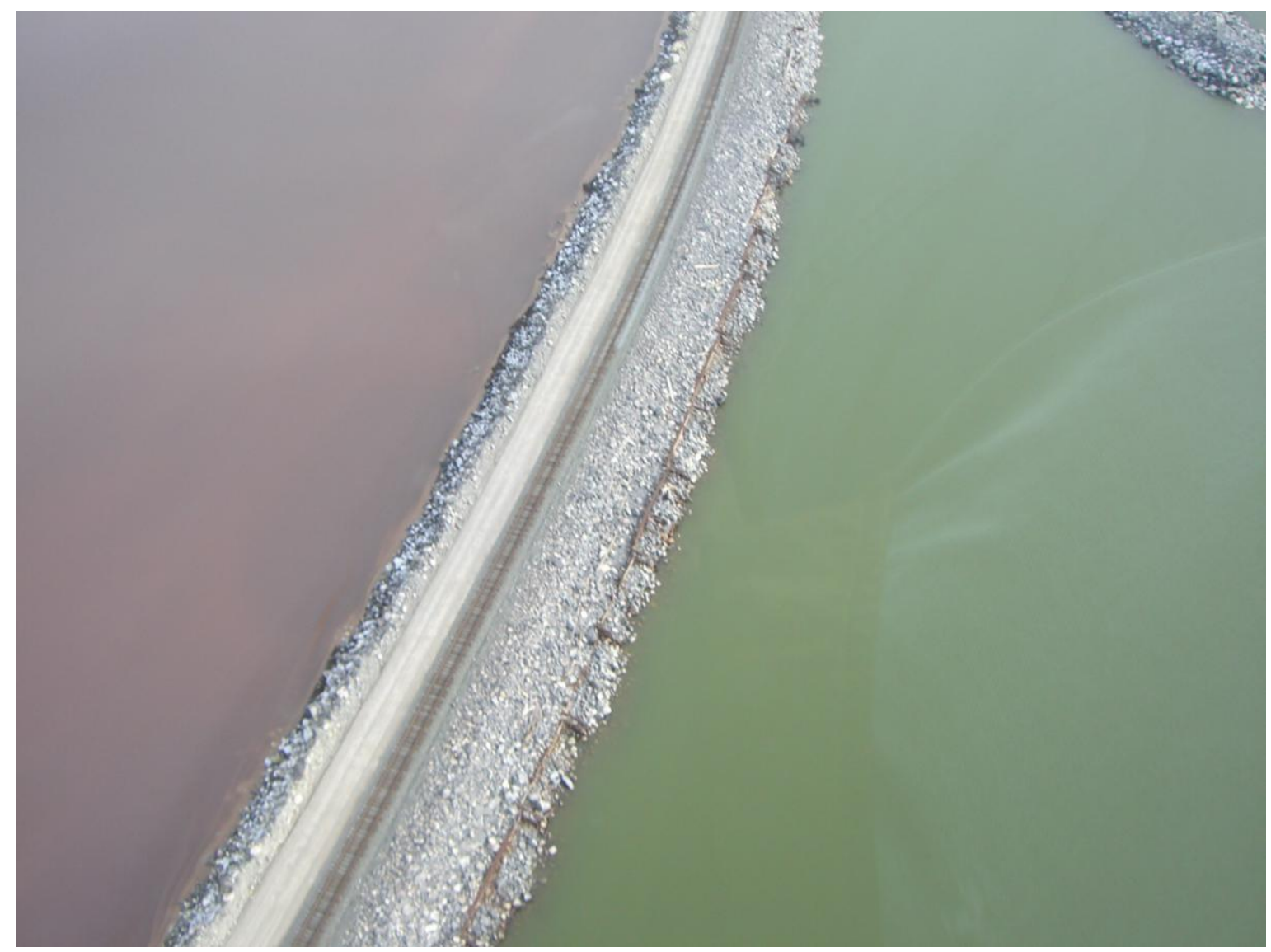

Figure 3: North and south sides of the railway causeway.

Although studies have been done concerning cyanobacteria inhabiting harsh hypersaline waters such as the Great Salt Lake, (Brock 1976, Butts 1980, Felix and Rushforth 1978), Marcarelli et al 2006, Oren 2002, Post 1981, Stephens and Gillespie 1976, and Sturm 1980), I have found no previous studies that have been performed on Gause's principle as applied to cyanobacteria of the Great Salt Lake.

\section{Great Salt Lake Cyanobacteria and Gause's Principle}

The question of whether the north species are out-competed in the south waters by the southern species is similar to the question pursued by the microbiologist Gause (1969) who derived what we now know as Gause's Principle: two similar species cannot indefinitely share the same niche because one of the other species will competitively 
exclude the other. One author summed up Gause's Principle as “complete competitors cannot coexist" (Hardin 1960). Empirical verification of Gause's Principle was originally provided by competition experiments on Paramecium aurelia and $P$. caudatum growing in mixed culture, where "Paramecium caudatum gradually diminished as a result of its being driven out by P. aurelia" (Gause 1969). Gause's principle became foundational in ecology, and is cited in most textbooks: "Two similar species scarcely ever occupy similar niches, but displace each other in such a manner that each takes possession of certain particular kinds of food and modes of life in which it has an advantage over its competitor" (Gause 1969).

Gause's principle is conceptually important in the formation of modern ecological theory and has been used to help derive the theoretical basis of island biogeography, as well as providing an ecological engine for evolutionary change. Clearly this is the basis for adaptive radiation in evolutionary ecology and competitive exclusion. Although the principle has often been applied to develop theory, there have been only few other experimental verifications of Gause's principle.

Since the Great Salt Lake is divided into salinity regimes by two causeways- a railway causeway which separates the northern arm of the lake from the southern portion, and a vehicular causeway from Syracuse, Utah to the northern tip of Antelope Islandthese causeways allow a test of Gause's principle. The waters south of each causeway are less saline (because of fresh water inputs) than the waters north of each causeway. Aerial photographs (Fig. 3) show the water on either side of the causeways to be colored differently, which suggests that the different salinity regimes of the lake maintain different algal and cyanobacterial floras. 
The main purpose of my study was to determine whether cyanobacterial distributions in the Great Salt are influenced by abiotic factors, biotic factors, or both. To test this question, experiments were designed to examine two hypotheses:

Hypothesis 1: Cyanobacterial species abundant north of the railway causeway are competitively excluded from the south by other species.

Hypothesis 2: Cyanobacterial species that thrive and bloom south of the Antelope causeway cannot grow in the high salinity of the north.

\section{Methods}

\section{A. Experimental Cultures}

A total of 28 water samples from both the north and south sides of Antelope Island causeway and the north and south sides of the railway causeway (seven from each site) were collected in December 2007 (Fig. 4, 5). Since the Antelope Island causeway is accessible to vehicles, water collections could be made by driving to the center of the causeway. Sample sites were chosen based on distance from the two fifteen-foot culverts that link both sides of the lake and accessibility to sufficiently deep water levels. Samples were collected from either side of the Union Pacific railway causeway to the area west of the remote Promontory peninsula, by parking a vehicle next to the tracks.

Digital thermometers were used to take the temperatures of the water on each side of the causeways and the GPS coordinates of the sample sites were recorded.

To avoid pseudoreplication, six water samples from both sides of the Antelope and railway causeways, approximately four liters in volume, were labeled as inocula. The seventh jar from each side was approximately eight liters in volume and labeled as media. The media water was filtered using $185 \mathrm{~mm}$ Whatman grade 3 filter paper. 
Approximately $30 \mathrm{ml}$ of the filtered media water was placed in autoclavable, sterile $50 \mathrm{ml}$ nalgene plastic flasks.

In total there were 96 flasks (Table 1). Each of the 96 flasks were inoculated with approximately $10 \mathrm{ml}$ of unsterilized water from either the north or the south Great Salt Lake water causeways totaling six replicates of inoculum water for each medium type. No nutrients or other growth media were added to the water, which is a newer technique of isolating rare bacteria from nature (Dyer 2003).

For the competition experiments, $30 \mathrm{ml}$ of media water were autoclaved, and then $5 \mathrm{ml}$ of inoculum from both the north and south sides of the causeways (north and south railway together, and Antelope north and south together) were added. A random number table was used to decide which sample jars to draw the inoculum from. There were a total of 12 competition experiments.

In addition to the other experiments, 20 control flasks were prepared using autoclaved media and autoclaved inocula. A random number table was used to decide from which sample jars to draw the inoculum. In addition, one control flask was prepared which consisted of autoclaved distilled water inoculated into autoclaved distilled water medium (refer to Tables 1-3 for experimental design). 


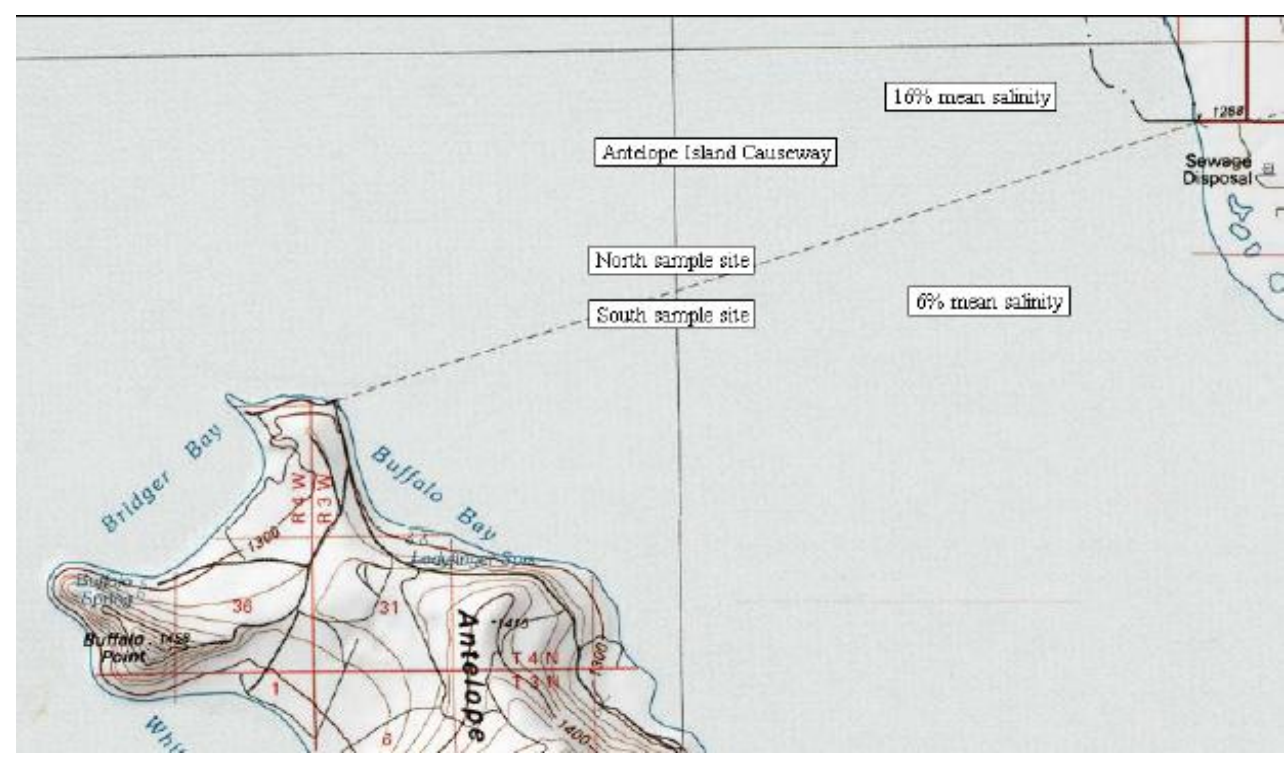

Figure 4: Antelope Island Causeway.

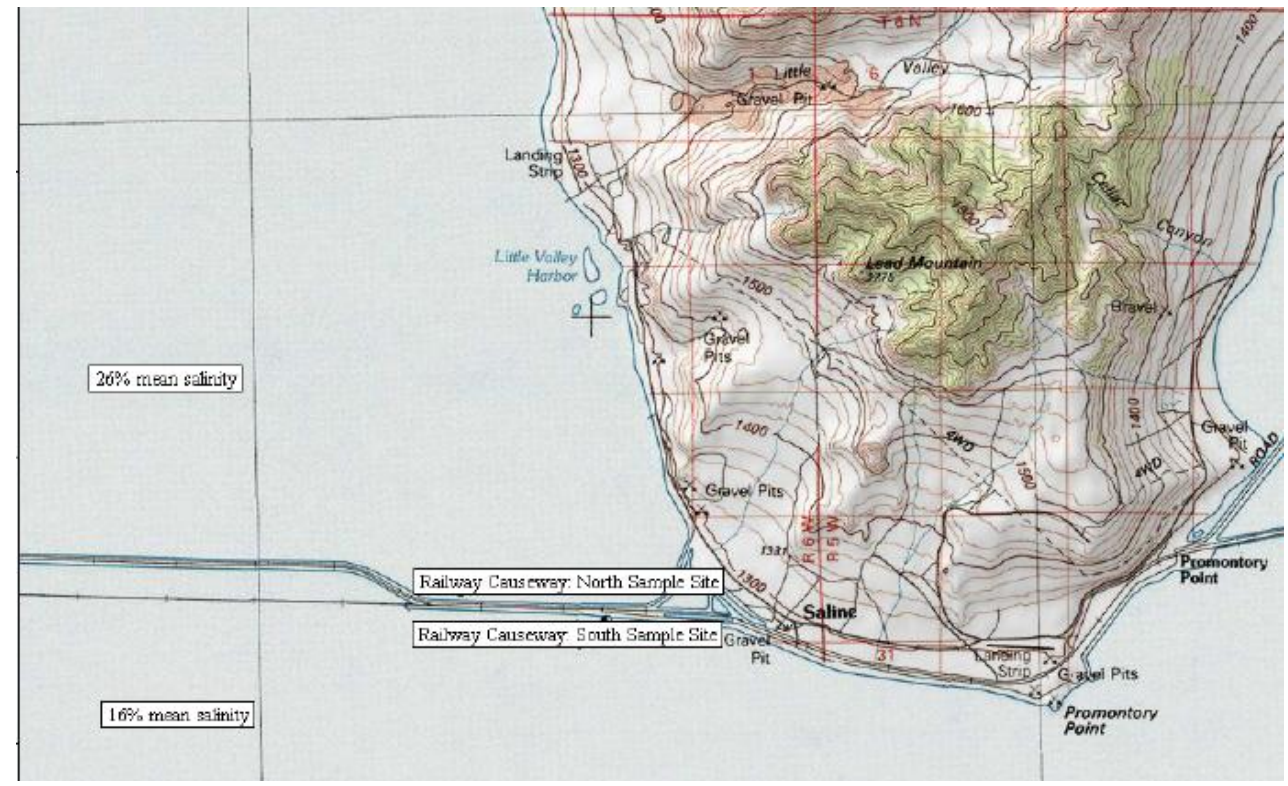

Figure 5: The railway causeway. 
Table 1: Media and Inocula Setup

Autoclaved Media

\begin{tabular}{|l|l|l|l|l|}
\hline $\begin{array}{c}\text { Inocula } \\
\downarrow\end{array}$ & Rail North & Rail South & $\begin{array}{c}\text { Antelope } \\
\text { North }\end{array}$ & $\begin{array}{c}\text { Antelope } \\
\text { South }\end{array}$ \\
\hline RN1 & 1 & 1 & 1 & 1 \\
\hline RN2 & 1 & 1 & 1 & 1 \\
\hline RN3 & 1 & 1 & 1 & 1 \\
\hline RN4 & 1 & 1 & 1 & 1 \\
\hline RN5 & 1 & 1 & 1 & 1 \\
\hline RN6 & 1 & 1 & 1 & 1 \\
\hline RS1 & 1 & 1 & 1 & 1 \\
\hline RS2 & 1 & 1 & 1 & 1 \\
\hline RS3 & 1 & 1 & 1 & 1 \\
\hline RS4 & 1 & 1 & 1 & 1 \\
\hline RS5 & 1 & 1 & 1 & 1 \\
\hline RS6 & 1 & 1 & 1 & 1 \\
\hline AN1 & 1 & 1 & 1 & 1 \\
\hline AN2 & 1 & 1 & 1 & 1 \\
\hline AN3 & 1 & 1 & 1 & 1 \\
\hline AN4 & 1 & 1 & 1 & 1 \\
\hline AN5 & 1 & 1 & 1 & 1 \\
\hline AN6 & 1 & 1 & 1 & 1 \\
\hline AS1 & 1 & 1 & 1 & 1 \\
\hline AS2 & 1 & 1 & 1 & 1 \\
\hline AS3 & 1 & 1 & 1 & 1 \\
\hline AS4 & 1 & 1 & 1 & 1 \\
\hline AS5 & 1 & 1 & 1 & 1 \\
\hline AS6 & 1 & 1 & 1 & 1 \\
\hline & & & & $=96$ flasks \\
\hline
\end{tabular}


Table 2: Competition Experimental Setup

\begin{tabular}{|c|c|c|c|c|}
\hline \multicolumn{5}{|c|}{ Autoclaved Media } \\
\hline $\begin{array}{c}\text { Inocula } \\
\downarrow\end{array}$ & Rail North & Rail South & $\begin{array}{l}\text { Antelope } \\
\text { North }\end{array}$ & $\begin{array}{l}\text { Antelope } \\
\text { South }\end{array}$ \\
\hline RN7+RS7 & 1 & & & \\
\hline RN7+RS7 & & 1 & & \\
\hline RN4+RS4 & 1 & & & \\
\hline RN4+RS4 & & 1 & & \\
\hline RN6+RS6 & 1 & & & \\
\hline RN6+RS6 & & 1 & & \\
\hline AN2+AS2 & & & 1 & \\
\hline AN2+AS2 & & & & 1 \\
\hline AN3+AS23 & & & 1 & \\
\hline AN3+AS3 & & & & 1 \\
\hline AN4+AS4 & & & 1 & \\
\hline AN4+AS4 & & & & 1 \\
\hline
\end{tabular}

Table 3: Control Experimental Setup

Autoclaved media

\begin{tabular}{|c|c|c|c|c|c|}
\hline $\begin{array}{l}\text { Autoclaved } \\
\text { Inocula } \downarrow\end{array}$ & Rail North & Rail South & $\begin{array}{c}\text { Antelope } \\
\text { North }\end{array}$ & $\begin{array}{c}\text { Antelope } \\
\text { South }\end{array}$ & Water \\
\hline RN5 & 1 & & & & \\
\hline RN5 & & 1 & & & \\
\hline RN5 & & & 1 & & \\
\hline RN5 & & & & & \\
\hline RS5 & 1 & & & & \\
\hline RS5 & & 1 & & & \\
\hline RS5 & & & & & \\
\hline RS5 & & & & & \\
\hline AN1 & 1 & & & & \\
\hline AN1 & & 1 & & & \\
\hline AN1 & & & & & \\
\hline AN1 & 1 & & & & \\
\hline AS3 & 1 & 1 & & & \\
\hline AS3 & & & & & \\
\hline AS3 & & & & & \\
\hline AS3 & & & & & \\
\hline Water & 1 & & & & \\
\hline Water & & & & & \\
\hline Water & & & & & \\
\hline Water & & & & & \\
\hline
\end{tabular}


After all 129 flasks were inoculated, they were placed in a heated green house.

Growth lights provided constant 8.5 hour/ day illumination. Each flask was gently shaken periodically for aeration. These liquid cultures were incubated for 7 weeks (Fig. 6).

\section{B. Identification of Cyanobacteria}

In their manual on aquatic cyanobacteria, Gertrud Cronberg and Helene Annadotter state that to identify cyanobacteria, light microscopy, phase and/or

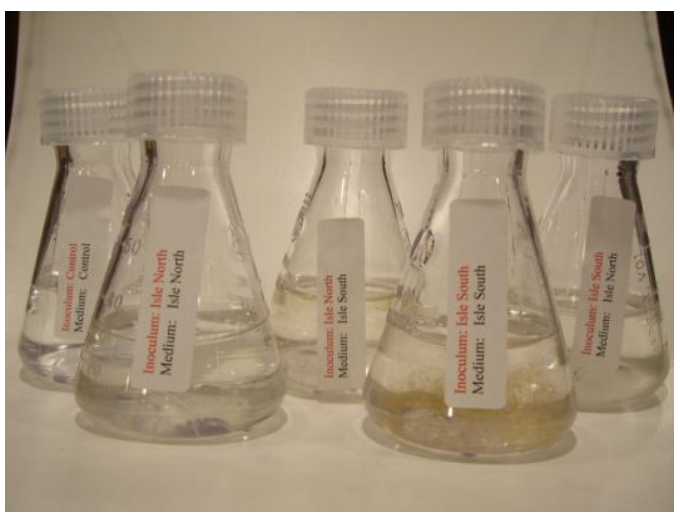
interference contrast, and sometimes electron microscopy should be used (Cronberg and Annadotter 2006). Identification and abundance counts of the cyanobacteria from the Great Salt

Lake were performed using a Zeiss Axioplan microscope with differential interference

Figure 6: Liquid cultures

contrast imaging and epi- fluorescence imaging at the Institute for Ethnomedicine Research Center in Jackson Hole, Wyoming. Scanning Electron Microscope (SEM) photos were taken to verify species in the culture flasks. The SEM protocols for each sample were strictly followed:

1) Fix in $2 \%$ Glutaraldehyde ( .06M cacodylate)

2) Wash in washing buffer (.03M sodium cacodylate) $6 \mathrm{X} 10$ minutes each

3) Stain and fix with $\mathrm{O}_{\mathrm{s}} \mathrm{O}_{4}$ (osmium tetroxide)

4) Rinse with distilled water 6 X10 minutes each

5) Place in filter paper pouch

6) Dehydrate with acetone series: 10\%, 30\%, 50\%, 70\%, 95\%, 100\%

7) Pelco critical point dry

8) Mount on stub with two sided conductive tape

9) Polaron E5300 gold sputter coating 


\section{Data Analysis Methods}

Two slides from each flask were prepared, with two sweeps of each slide counted to determine relative species abundance. Counts were recorded on a six-cell mechanical lab counter, with four common Great Salt Lake cyanobacterial species (Aphanothece halophytica, Oscillatoria sp., Phormidium tenue, and Nodularia spumigena) labeled on a specific button. In addition to cyanobacterial species, one button was also labeled for the green alga Dunaliella spp.

For ease of analysis, the counts of the two slides were summed. In the case of mass colonies of cyanobacteria where individual numbers were high, the colony was counted as either " 500 " for large colonies or " 1000 " for very large colonies.

In each of the sixteen possible combinations of four types of media (railway north, railway south, Antelope north, and Antelope south) and four types of inocula (railway north, railway south, Antelope north, and Antelope south), the median counts of the four major cyanobacterial species (Aphanothece halophytica, Oscillatoria sp., Phormidium tenue, and Nodularia spumigena) were ranked and recorded.

A two-way Analysis of Variance (ANOVA) was calculated for abundance of Aphanothece halophytica and the green alga Dunaliella spp. in the culture flasks, using hand calculations entered on an Excel spreadsheet. The results were checked with the computer program SAS. F statistics were calculated for each species to test three different pairs of hypotheses:

Hypothesis pair \#1

$\mathrm{H}_{\mathrm{o}}$ : There is no variation in cyanobacterial or algal counts due to differences in media. 
$\mathrm{H}_{1}$ : There is variation in cyanobacterial or algal counts due to differences in media.

Hypothesis pair \#2

$\mathrm{H}_{\mathrm{o}}$ : There is no variation in cyanobacterial or algal counts due to differences in inocula.

$\mathrm{H}_{1}$ :There is variation in cyanobacterial or algal counts due to differences in inocula.

Hypothesis pair \#3

$\mathrm{H}_{\mathrm{o}}$ : There is no variation in cyanobacterial or algal counts due to interactions between differences in media and inocula.

$\mathrm{H}_{1}$ : There is variation in cyanobacterial or algal counts due to interactions between differences in media and inocula.

Each hypothesis was tested for significance, with the null hypothesis to be rejected at the $\mathrm{p}<0.05$ level. Square root transformations were used on the two ANOVAS, which is common for count data.

Given the absence of the cyanobacterial taxa Nodularia spumigena, Phormidium tenue, and Oscillatoria sp. from many (but not all) of the culture flasks, a two-way ANOVA was not an appropriate statistical technique for data analysis, and so exact logistic tests were calculated. 


\section{Results and Discussion}

\section{A. Experimental cultures}

Sampling for the experimental cultures of Great Salt Lake water on the north and south side of the railway causeway exhibited profoundly different colors when observed from the air (Fig. 3). This color difference was confirmed when the samples were collected on either side of the causeway (Fig. 7). Water samples from north of the railway causeway appeared distinctly reddish while water samples from the south side of the railway causeway appeared to be greenish. Salinity readings of the four types of media measured by hydrometers also differed: waters from the south side of Antelope causeway were $20.6 \mathrm{ppt}$, waters from north of the Antelope causeway were $75 \mathrm{ppt}$, waters from south of the railway causeway were $155 \mathrm{ppt}$, and waters north of the railway causeway were 195ppt (Roney 2007). Salinity values of the flasks were altered slightly by addition of inocula, except when the same inoculum was added to the same medium.

At the time of sampling (December 14, 2007), the ambient air temperature on the

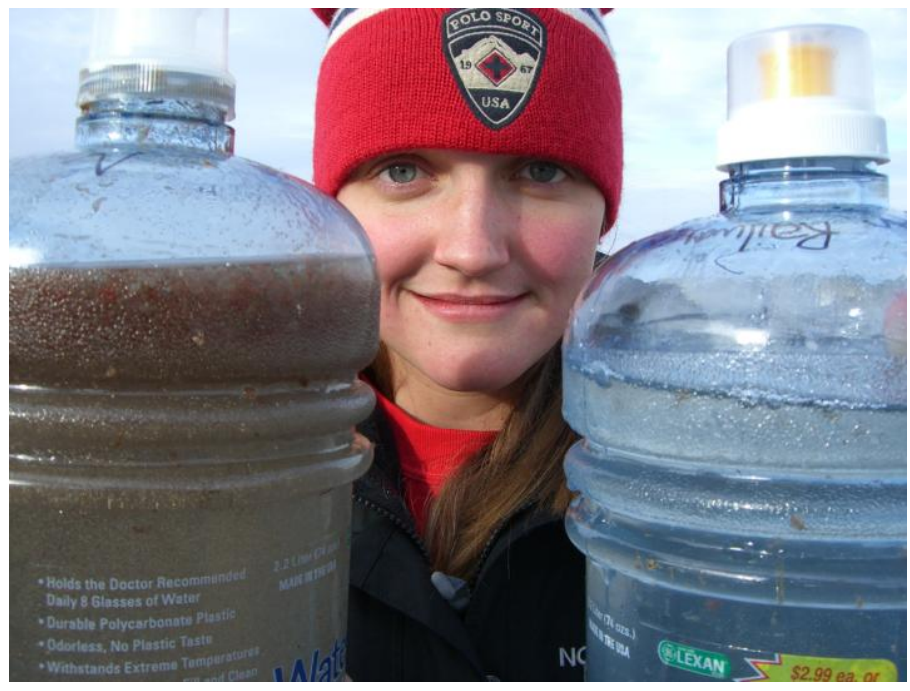

Figure 7: Samples from the north and south side of the railway causeway. railway causeway was $-2.2 \mathrm{C}$.

Water temperatures north of the

railway causeway measured 2.0

$\mathrm{C}$, and the water temperatures

south of the railway causeway

measured 4.3 C. The GPS

coordinates of the railway causeway sample site were $\mathrm{N} 41^{\circ}$ 13'16' W $112^{\circ} 32$ '34'. The

ambient air temperature at the Antelope Island causeway was $-2.8 \mathrm{C}$. The waters north of 
Antelope Island causeway measured 3.3, while the water temperature south of the Antelope Island causeway measured $2.5^{\circ}$ Celsius. The GPS coordinates of the Antelope Island sample site were N $41^{\circ} 4^{\prime} 44^{\prime \prime}$ W $112^{\circ} 12^{\prime} 57^{\prime \prime}$.

The twelve competition experiments were not productive, and after the initiation of the experiments, it was realized that axenic cultures should have first been obtained to perform competition experiments. Isolation of Great Salt Lake cyanobacterial species in axenic culture was determined to be beyond the scope of the present thesis. Analysis by light microscopy showed no growth in any of the 21 controls, which were found to be sterile.

\section{B. Identification of Cyanobacteria}

Four genera of cyanobacteria, Aphanothece, Oscillatoria, Phormidium and Nodularia, were tentatively identified and counted from the culture flasks using comparative differential interference contrast, fluorescence and scanning electron microscopy (Figs. 10-13). Dr. James Metcalf from the University of Dundee, Scotland confirmed cyanobacterial identifications. In addition, a fifth cyanobacterial species was observed, but was not found in a transect through any of the microscope slides. This cyanobacterial species seems, because of the size of its trichomes and its affinity for saline waters, most like Spirulina labyrinthiformis, although previous authors may have recorded the same cyanobacterium as Spirulina major. I note that Nübel et al (2000) have segregated the clade of salt-tolerant species as a new genus, Halospirulina, but at this point it is unclear if raising this clade within Spirulina (synonym Arthospira) to generic status will be universally accepted by cyanobacterial experts. There were also

other unidentified cyanobacterial species found. Comparisons between differential 
interference contrast microscopy, fluorescence microscopy, and scanning electron microscopy allowed different observations of cyanobacterial morphology and size to be compared for taxonomic identification.

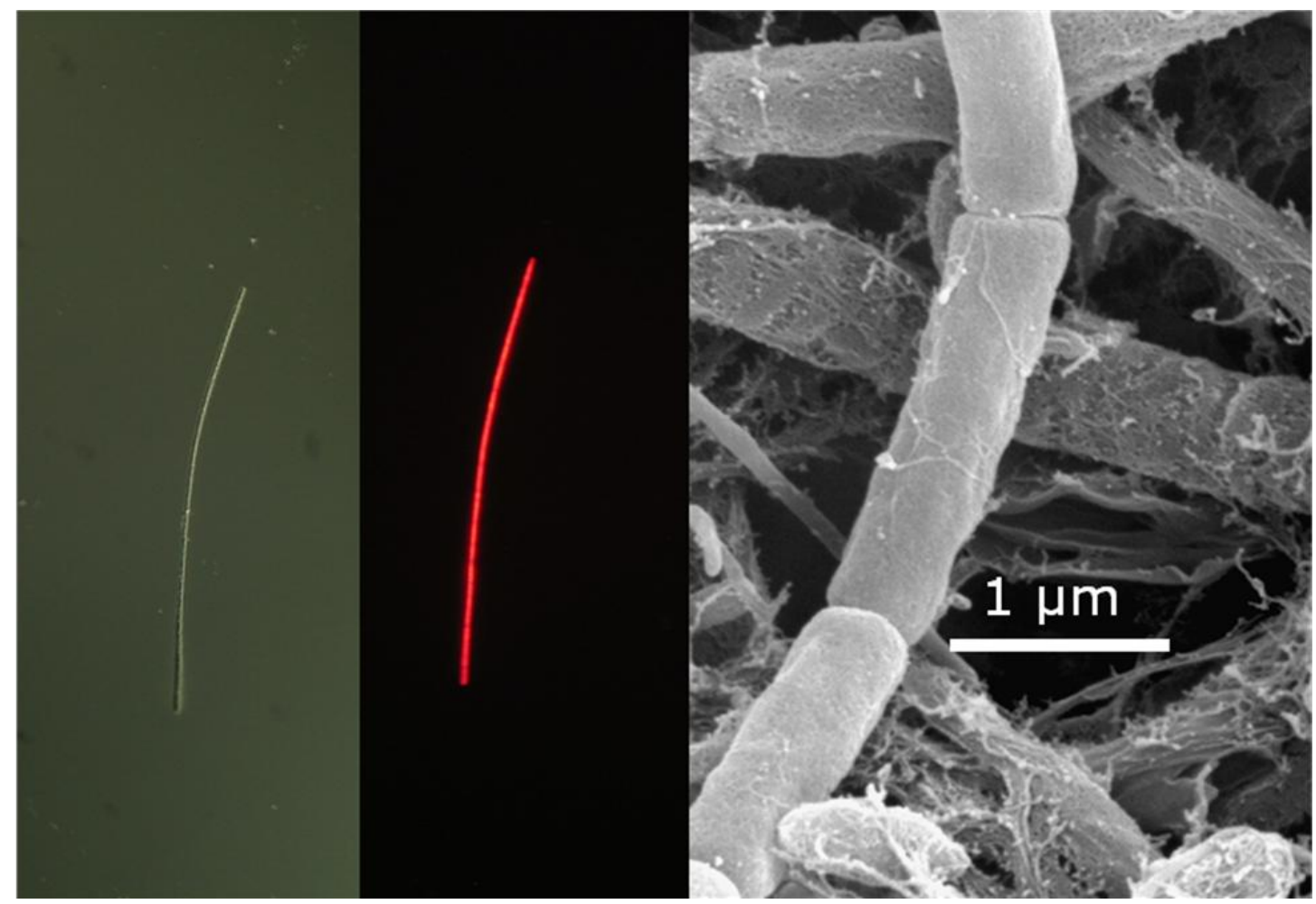

Figure 8: Oscillatoria spp. left: Differential Interference Contrast Microscopy; middle: Fluorescence Microscopy; right: Scanning Electron Microscopy 


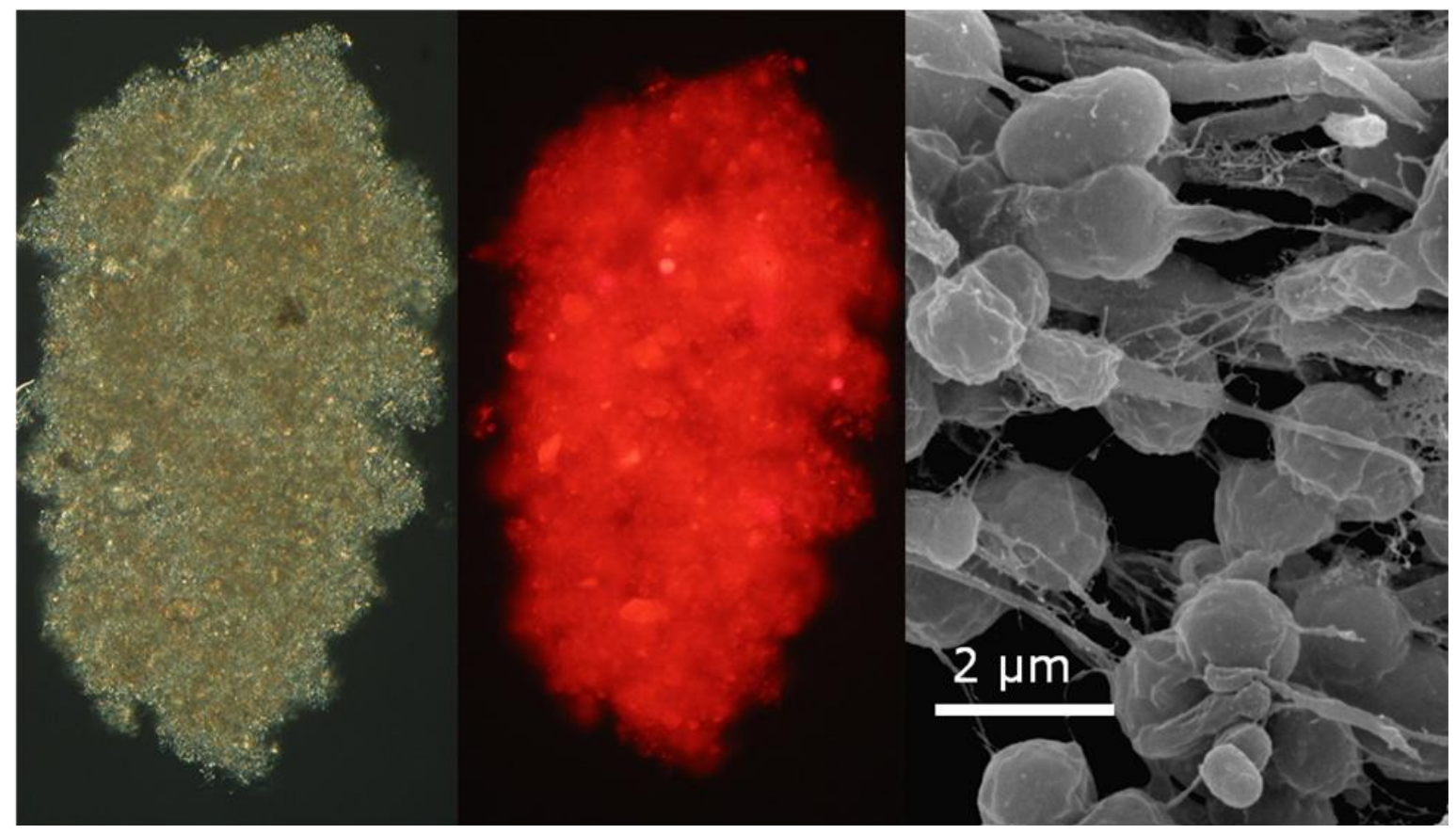

Figure 9: Aphanothece halophytica left: Differential Interference Contrast Microscopy; middle: Fluorescence Microscopy; right: Scanning Electron Microscopy

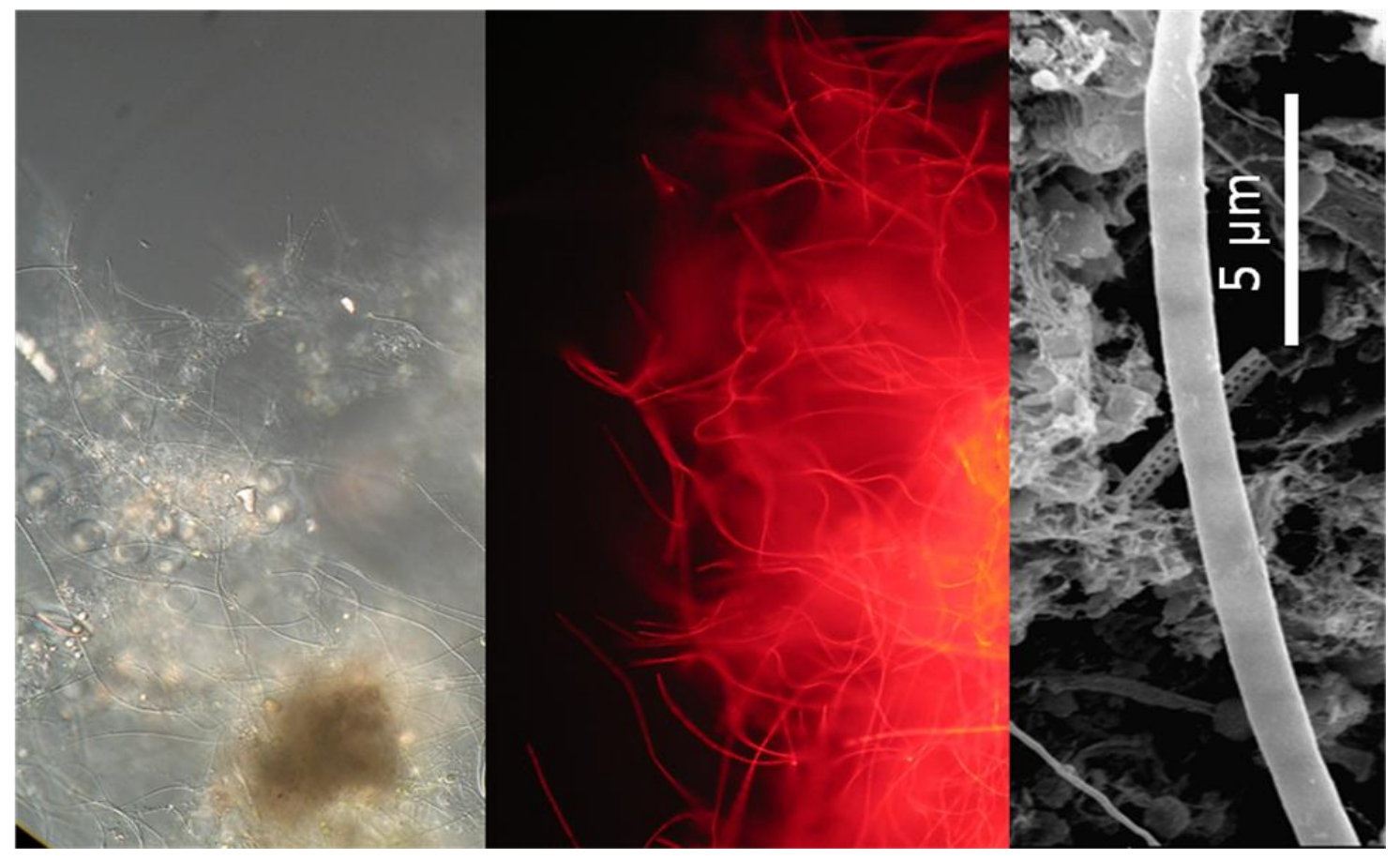

Figure 10: Phormidium tenue left: Differential Interference Contrast Microscopy; middle: Fluorescence Microscopy; right: Scanning Electron Microscopy. 


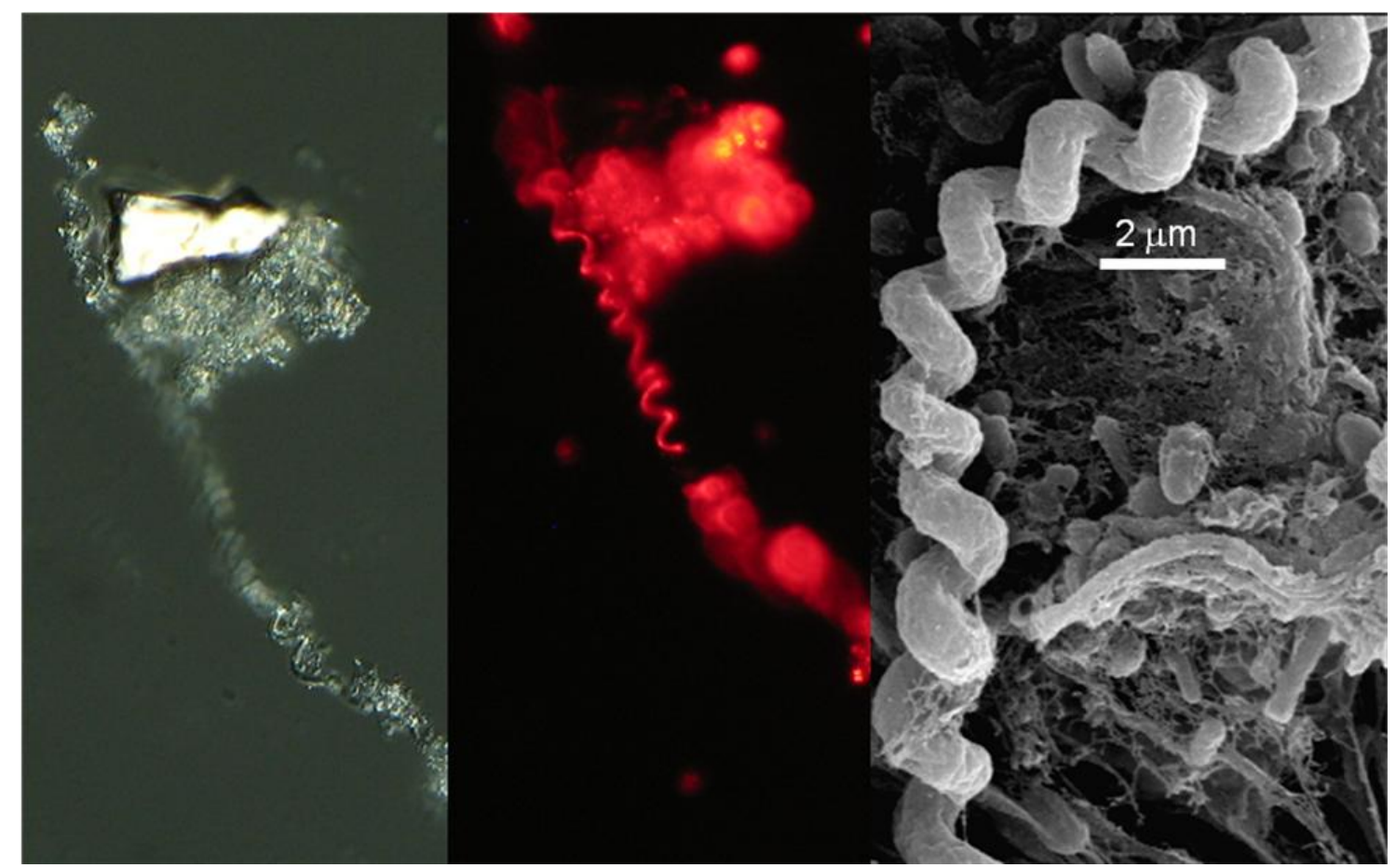

Figure 11: Spirulina labyrinthiformis. left: Differential Interference Contrast Microscopy; middle: Fluorescence Microscopy; right: Scanning Electron Microscopy

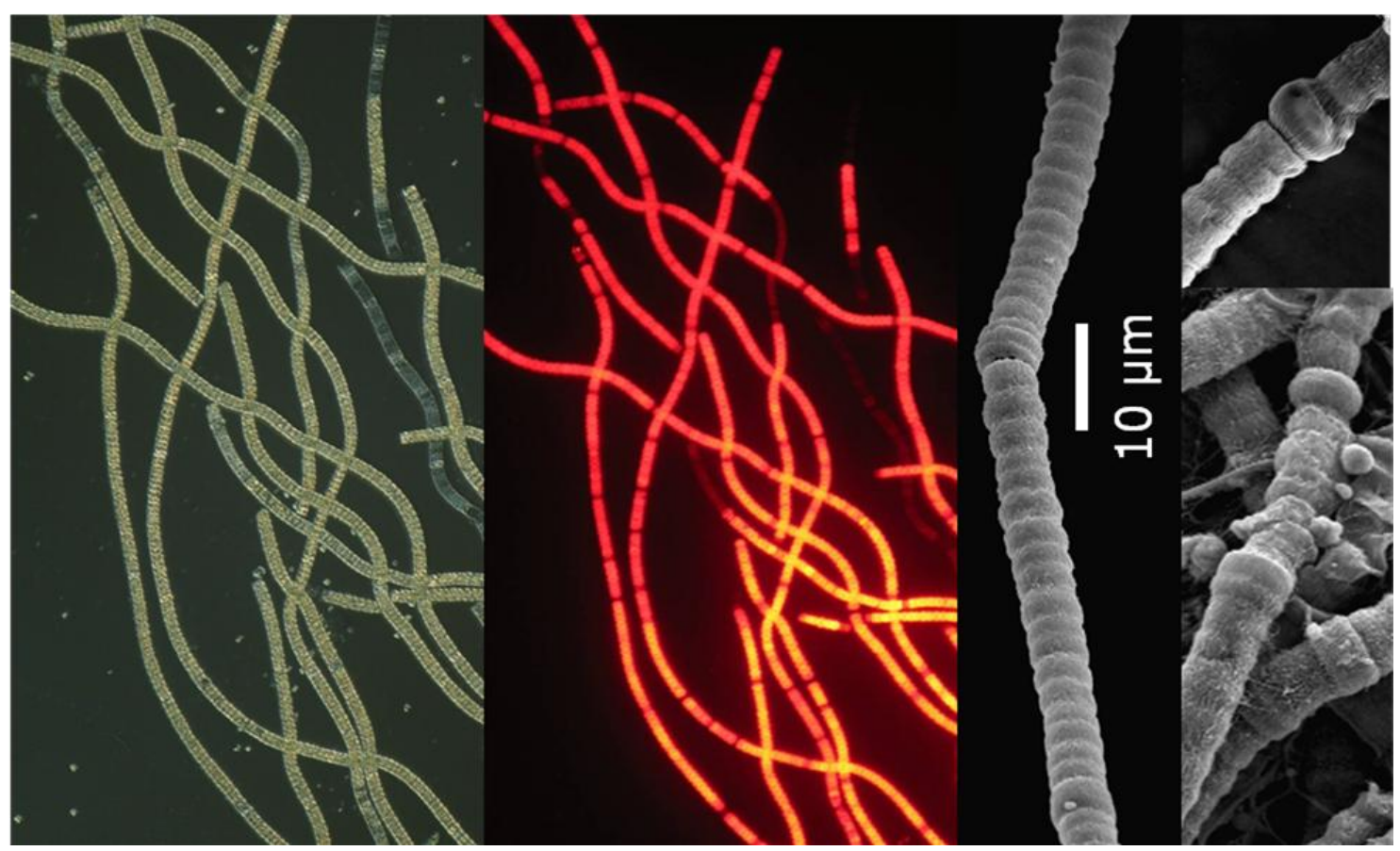

Figure 12: Nodularia spumigena. left: Differential Interference Contrast Microscopy; middle: Fluorescence Microscopy; right: Scanning Electron Microscopy. 


\section{Data Analysis}

The comparative means of the four major cyanobacteria for each inocula type in the four media are shown in Figure 13. This Figure demonstrates that Aphanothece halophytica appears throughout all the four types of media and inocula, but that Nodularia spumigena is abundant only in inocula from Antelope south waters.
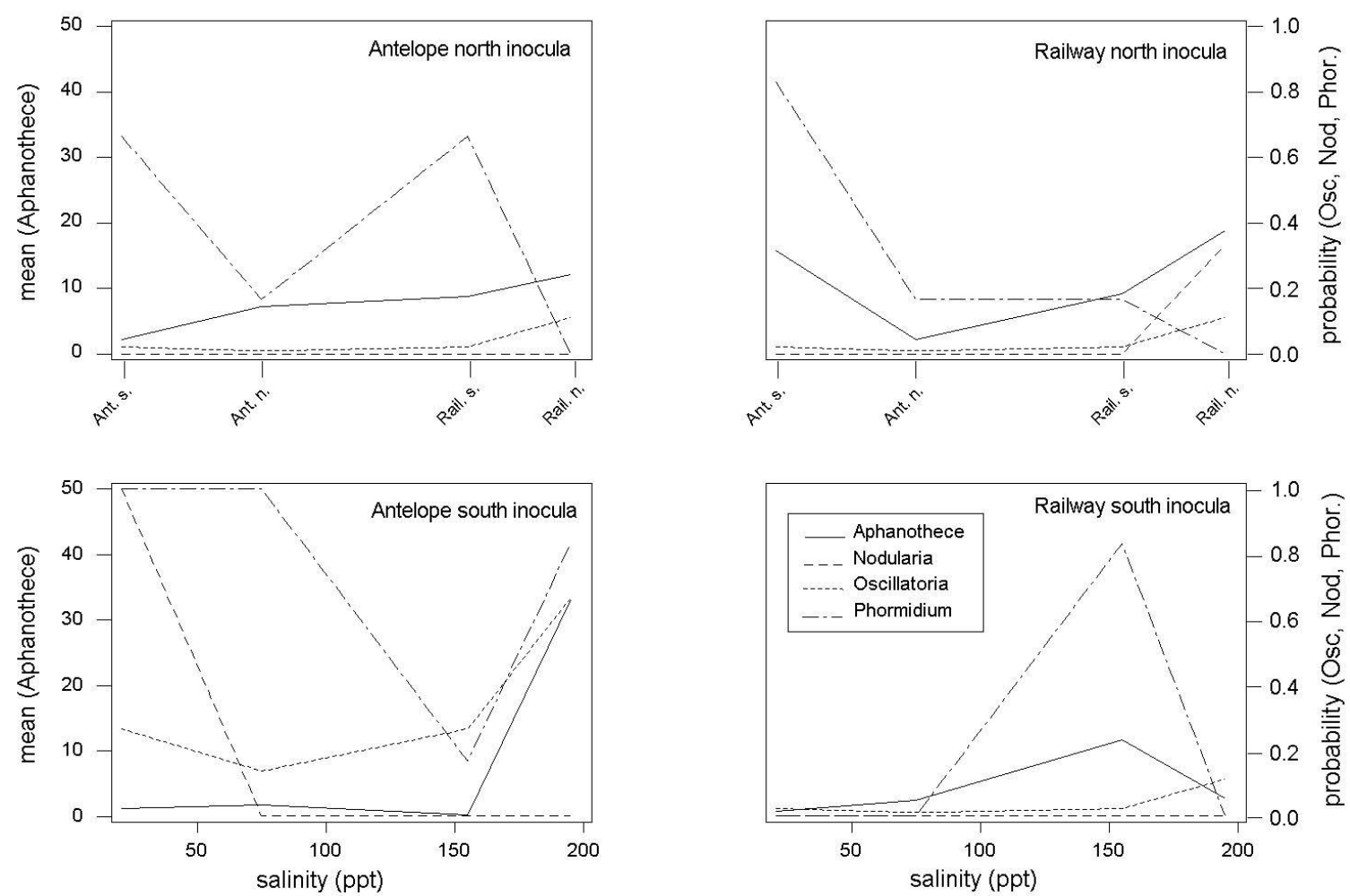

Figure 13: Comparative Means of Aphanothece and probabilities of Oscillatoria, Nodularia and Phormidium for each inocula type in the four media.

Since there are 24 different permutations of the ordered ranks of Aphanothece (A), Oscilatoria $(\mathrm{O})$, Nodularia $(\mathrm{N})$, and Phormidium $(\mathrm{P})$ plus an additional 16 permutations of three and two-way ties, as well as one possible case of a four-way tie in rank, there are 41 different possible rankings of the four cyanobacterial species. Each possible rank 
order of species abundance was therefore assigned a number ranging from 1 to 41 , and entered into a table for each of the sixteen different inocula/media combinations (Table 4). The ranking $\mathrm{P}, \mathrm{A}, \mathrm{O}, \mathrm{N}$ was arbitrarily assigned the number 1 , the $\operatorname{rank} \mathrm{P}, \mathrm{N}, \mathrm{A}, \mathrm{O}$ was assigned the number 2 , the rank $\mathrm{A}, \mathrm{P}$, with $\mathrm{N}$ and $\mathrm{O}$ tied was assigned the number 3 , the rank $\mathrm{A}$, with $\mathrm{P}, \mathrm{N}$, and $\mathrm{O}$ tied was assigned the number 4 , and the four way tie of all species (including all having a median abundance of 0 ) was assigned the number 5 . Thus the ordinal data have been transformed into nominal data.

Table 4: Ranked orders of Aphanothece, Oscillatoria, Nodularia, and Phormidium.

\begin{tabular}{|c|c|c|c|c|}
\hline \multicolumn{5}{|c|}{ Medium } \\
\hline Inoculum & Rail North & Rail South & Antelope North & Antelope South \\
\hline Rail North & 4 & 4 & 5 & 3 \\
\hline Rail South & 4 & 3 & 4 & 5 \\
\hline Antelope North & 4 & 3 & 4 & 3 \\
\hline Antelope South & 1 & 3 & 3 & 2 \\
\hline
\end{tabular}

For ease of discussion, these different rankings can perhaps most easily be portrayed as different colors (Table 5). For the sixteen possible combinations of four types of media (Railway North, Railway South, Antelope North, and Antelope South) and four types of inocula (Railway North, Railway South, Antelope North, and Antelope South), the median counts of the four major cyanobacterial species (Aphanothece halophytica , Oscillatoria sp., Nodularia spumigena, and Phormidium tenue ) were ranked and shown in Table 5. 
Table 5: Cyanobacteria ranking by medians.

\section{Cyanobacteria Ranking by Medians}

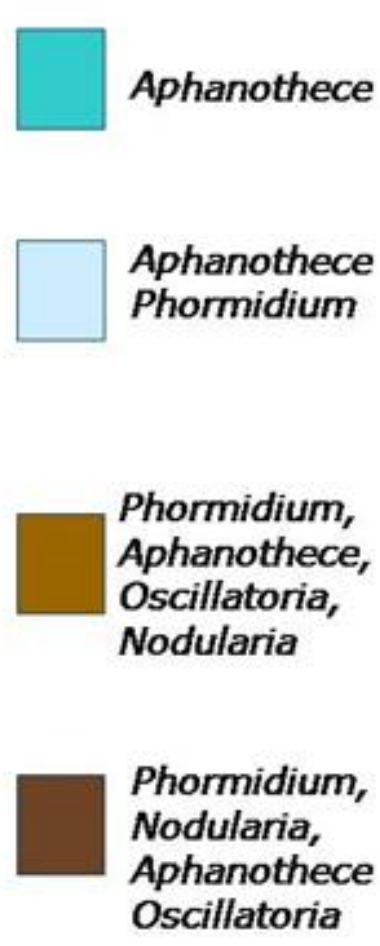

Media

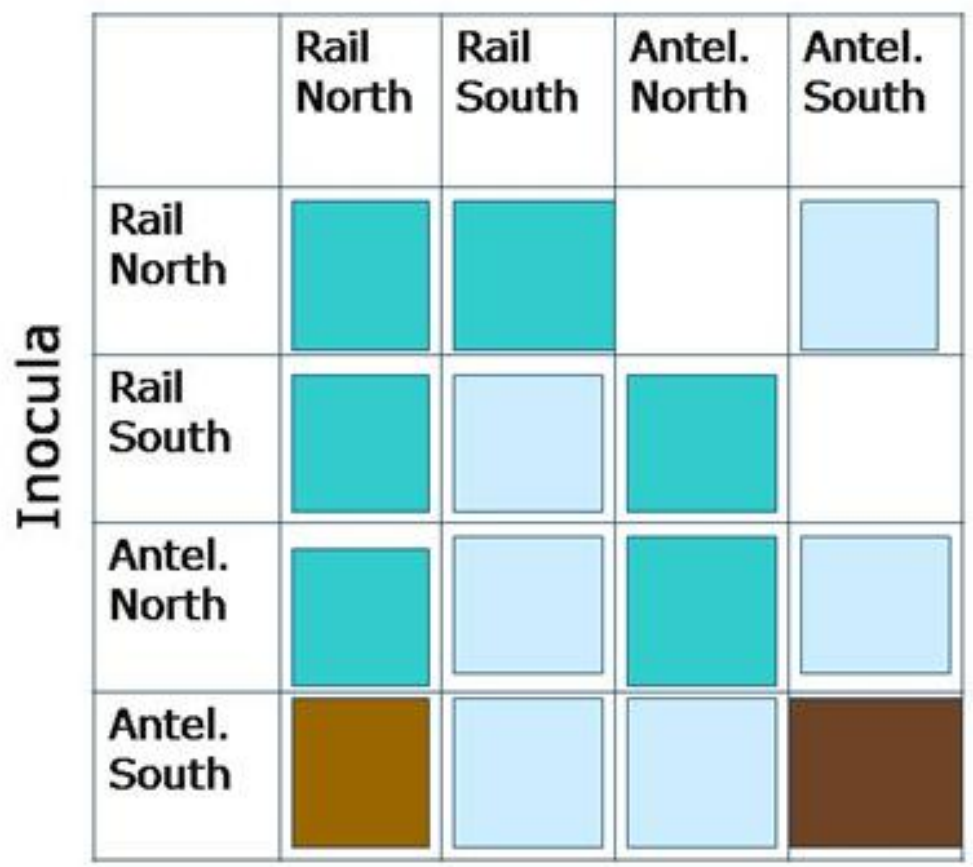

As can be seen in Table 5 (above), Aphanothece halophytica was dominant in all cultures flasks, except those in which Nodularia spumigena and Oscillatoria sp. occurred.

Two-way ANOVA for the distributions of Aphanothece halophytica and Dunaliella spp. were performed as indicated in Table 6 and Table 7.

Table 6: ANOVA of Aphanothece halophytica counts in experimental media from autoclaved Great Salt Lake water

\begin{tabular}{|c|c|c|c|c|c|}
\hline Source & Variation & Degrees Free & Mean Square & F statistic & Significance \\
\hline Media & 64.6 & 3.0 & 21.5 & 11.4 & $p<0.01$ \\
\hline Inocula & 26.1 & 3.0 & 8.7 & 4.6 & $p<0.01$ \\
\hline Interaction & 105.6 & 9.0 & 11.7 & 6.2 & $p<0.01$ \\
\hline Subtotal & 196.3 & 15.0 & & & \\
\hline Error & 151.1 & 80.0 & 1.9 & & \\
\hline Total & 347.4 & 95.0 & & & \\
\hline
\end{tabular}


Table 7: ANOVA of Dunaliella spp. counts in experimental media from autoclaved Great Salt Lake water

\begin{tabular}{|c|c|c|c|c|c|}
\hline Source & Variation & Degrees Free & Mean Square & F statistic & Significance \\
\hline Media & 446.4 & 3.0 & 148.8 & 5.8 & $p<0.01$ \\
\hline Inocula & 495.1 & 3.0 & 165.0 & 6.5 & $p<0.01$ \\
\hline Interaction & 1959.3 & 9.0 & 217.7 & 8.5 & $p<0.01$ \\
\hline Subtotal & 2900.8 & 15.0 & & & \\
\hline Error & 2039.8 & 80.0 & 25.5 & & \\
\hline Total & 4940.6 & 95.0 & & & \\
\hline
\end{tabular}

As can be seen for Aphanothece halophytica in Table 6 and for Dunaliella spp. in Table 7, the F statistics for the ANOVAS allows each of the null hypotheses in the three pairs of hypotheses to be rejected at the $\mathrm{p}<0.05$ level. Therefore, it can be concluded that media and inocula, as well as the interaction between media and inocula significantly affected the growth of Aphanothece halophytica and Dunaliella in the culture flasks.

Exact tests were calculated for Nodularia spumigena and Oscillatoria spp. using the exact option of pro logistic in SAS. In these analyses, counts were ignored, and instead, presence/ absence data were used.

For Oscillatoria, the p-value for the exact test of the medium was 0.0993 ; thus the effect due to media differences was not significant. However, the p-value for the exact test of inoculum was 0.0016 ; hence there was a significant inoculum effect in distribution of Oscillatoria. The exact test for the inocula/media interactions was not significant with a p-value of 0.1963 . Leaving interaction out of the model, the additive model (with additive effects of inoculum and medium) showed the odds of a positive response for inocula from rail south, rail north, or Antelope north was just $6.3 \%$ relative to inoculum from Antelope south (95\% confidence interval: 0.6\% - 64.2\%). Thus, Antelope south 
inocula had a significant positive effect on the presence of Oscillatoria in the culture flasks.

A similar analysis was conducted for the presence or absence of Nodularia spumigena in the culture flasks. The exact test for the inocula/media interaction had a pvalue of 0.0032 ; hence the interaction was significant. The odds of a positive effect were extremely high for the combination of Antelope south inoculum with Antelope south media. For all other combinations, the odds of a positive response were extremely low.

Both the ranking of median abundances in the culture flasks and the results of the two way ANOVA support my overall hypothesis: cyanobacterial species abundant north of the railway causeway (e.g. Aphanothece halophytica) are competitively excluded from the south by other species, in this case Nodularia spumigena and Oscillatoria spp. It appears that the cyanobacterium Aphanothece halophytica can grow in less saline waters than the extreme saline waters north of the railway causeway - since it is found in all inocula - but its growth appears to be suppressed by the presence of Nodularia spumigena, which periodically blooms in the Great Salt Lake.

In previous years, I have noted large Nodularia blooms in the low salinity regime of Farmington Bay, as well as in water samples collected south of the railway causeway (Roney 2007). In 1982, Rushforth and Felix recorded Nodularia spumigena as rare in the south arm. Perhaps in 1982 the waters of the south arm of the Great Salt Lake had not been exposed to Nodularia blooms, or Felix and Rushforth took their samples at a dormant season, as in my research I have found that $N$. spumigena produces episodic blooms. The absence of $N$. spumigena in the southern arm may have influenced the ability of A. halophytica to migrate and prosper in the fresher water environment of the 
south arm instead of thriving in the hyper-saline north arm. Every time I have sampled south of the Antelope causeway since 2004, I have found N. spumigena present in the water column.

My second overall hypothesis that cyanobacterial species that thrive and bloom south of the Antelope causeway cannot grow in the high salinity of the north, is also supported by these data. Nodularia spumigena was found only in inocula from the less saline waters south of the Antelope Island causeway, and apparently cannot survive the high saline waters north of the railway causeway.

Experimental confirmation of these two hypotheses helps answer my original question: Are cyanobacterial distributions in the Great Salt Lake influenced by abiotic factors, biotic factors, or both? Indeed, both abiotic (salinity) and biotic (interspecies competition) seem to affect distributions of cyanobacterial species. $N$. spumigena distributions seem to be primarily influenced by salinity, which can only grow in fresher waters. By contrast, A. halophytica distributions seem to be primarily influenced by competition by N. spumigena and Oscillatoria sp.

These experimental data, therefore, are consistent with Gause's Law, which predicts that no two species can indefinitely occupy the same niche, but they add additional information. A. halophytica and N. spumigena cannot occupy the same hypersaline habitat north of the railway causeway - since $N$. spumigena cannot tolerate hypersaline conditions, and does not even occur in inocula from the northern waters in my sample - while growth of A. halophytica is consistently suppressed in the presence of N. spumigena. 
However, this leaves unanswered the question of why A. halophytica is not totally excluded from the south, since it occurs in all samples of inocula, regardless of salinity. I suggest that $A$. halophytica is periodically excluded from southern waters by $N$. spumigena blooms, but that in the intervals between blooms, this extremely small cyanobacterium can persist, albeit at levels far lower than in areas where Nodularia is not present. Thus, Gause's law should perhaps include a clarification: two species cannot indefinitely occupy the same niche, except for cases of episodic blooms or population explosions.

The relative abundances of cyanobacteria in the Great Salt Lake demonstrate an important truth about niche theory- that species can partition niches temporally as well as spatially.

To my knowledge no previous studies have been performed testing competitive exclusion of cyanobacteria in the Great Salt Lake. Since my results show that distributions of cyanobacteria in the Great Salt Lake are influenced by both abiotic as well as biotic factors it would be interesting to compare my data with the intermediate salinity hypothesis of David Herbst: "Abundance of salt-tolerant organisms is limited by physiological stress at high salinities, and by ecological factors, such as predation and competition, in more diverse communities at low salinities" (Herbst 1999). Since Nodularia spumigena distributions cannot survive the high salinity stress of the north arm of the Great Salt Lake, and Aphanothece halophytica distributions seem to be competitively excluded at lower salinities, the intermediate salinity hypothesis applies to my study. 


\section{Future Studies}

Based on the current study, five different approaches should be considered in future investigations:

1) Aphanothece and Nodularia should be grown in axenic cultures, and placed in competition trials to see how exactly Nodularia competes with Aphanothece.

2) Physiological tolerances for differing salinities of Aphanothece and Nodularia should be carefully measured. Sørensen et al. (2004) state that, "Members of such natural prokaryotic communities may have salt adaptations that are not reflected in culture collections, and studies of pure cultures should be supplemented with salinity response studies of natural communities in order to fully understand to what extent increased salinity limits prokaryotic growth.”

3) Microscopic identifications of the Great Salt Lake cyanobacteria should be confirmed with 16S rRNA studies (Castenholz and Norris 2005).

4) Temperature and nutrient conditions triggering Nodularia blooms should be identified.

5) The relationship between the green algae Dunaliella and the cyanobacteria in the Great Salt Lake should be closely examined to see how they compete and impact each other.

\section{References}

Brock, T. D. (1976). "Halophilic blue-green algae." Archives of Microbiology 107(1): 109-111.

Brown, J. R., C. J. Douady, et al. (2001). "Universal trees based on large combined protein sequence data sets." Nature Genetics 28: 281-285. 
Butts, D. S.(1980). "Factors affecting the concentration of Great Salt Lake Brines". Great Salt Lake: A Scientific, Historical, and Economic Overview. Ed. J. W. Gwynn. Salt Lake City: Utah Geological and Mineral Survey. 163.

Castenholz, R. W. (1992). "Species usage, concept, and evolution in the cyanobacteria (blue-green algae)." J. Phycol 28: 737-745.

Castenholz, R. W. and T. B. Norris (2005). "Revisionary concepts of species in the Cyanobacteria and their applications." Algological Studies (Cyanobacterial Research 6) 117: 53-69.

Cronberg, G. and H. Annadotter (2006). Manual of aquatic cyanobacteria: A photo guide and a synopsis of their toxicology. Copenhagen: International Society for the Study of Harmful Algae.

Darlington, P. J. (1972). "Competition, Competitive Repulsion, and Coexistence" PNAS 69: 3151- 3155.

Dyer, B. D. (2003). A Field Guide to Bacteria. New York: Cornell University Press.

Felix, E. A. (1978). "The Algal Flora of the Great Salt Lake." Provo: Department of Botany and Range Science Brigham Young University.

Felix, E.A. and S.R. Rushforth. (1980). "Biology of the South Arm of the Great Salt Lake, Utah." Great Salt Lake: A Scientific, Historical, and Economic Overview. Ed. J. W. Gwynn. Salt Lake City: Utah Geological and Mineral Survey. 305.

Gause, G.F. (1969). The Struggle for Existence. New York: Hafner Publishing Company.

Gwynn, J. W. (2002). Great Salt Lake: an overview of change. Salt Lake City: Utah Department of Natural Resources.

Hardin, G. (1960). "The competitive exclusion principle." Science 131: 1292- 1297. 
Herbst, D. B. (1999). "Biogeography and Physiological Adaptations of the Brine Fly Genus Ephydra (Diptera: Ephydridae) In Saline Waters of the Great Basin." Great Basin Naturalist 59(2): 127-135.

Hutchinson, G. E. (1961). "The paradox of the plankton." American Naturalist 95: 137-145.

Marcarelli, A. M., W. A. Wurtsbaugh, et al. (2006). "Salinity controls phytoplankton to nutrient enrichment in the Great Salt Lake, Utah, USA."Canadian Journal of Fisheries and Aquatic Sciences 63: 2236-2248.

Nübel, U., Ferran Garcia-Pichel, et al. (2000). "The halotolerance and phylogeny of cyanobacteria with tightly coiled trichomes (Spirulina turpin) and the description of Halospirulina tapeticola gen. nov., sp. nov." International Journal of Systematic and Evolutionary Microbiology 50: 1265-1277.

Oren, A. (2000). "Salts and Brines". The Ecology of Cyanobacteria. Ed. Brian A. Whitton and Malcolm Potts. Dordrecht: Kluwer Academic Publishers. 281.

Oren, A. (2002). Halophilic Microrganisms and their Environments. Dordrecht: Kluwer Academic Publishers.

Post, F. J. (1981). "Microbiology of the Great Salt Lake north arm " Hydrobiologia 81-82(1): 59-69.

R. Rippka, J. B. Deruelle, et al. (1979). "Generic assignments, strain histories and properties of pure cultures of cyanobacteria." J. Gen. Microbiol 111: 1-61.

Rodriguez-Valera, F. (1988). Halophilic Bacteria Volume I. Boca Raton: CRC Press, Inc.

Roney, Hillary (2007). "Competitive Exclusion of Cyanobacteria in the Great Salt Lake.” Provo: Department of Biology Brigham Young University. 
Rushforth, S. R. and E. A. Felix (1982). "Biotic adjustments to changing salinities in the Great Salt Lake, Utah, USA " Microbial Ecology 8(2): 157-161.

Schopf, J. W. (2000). "The fossil record: tracing the roots of the cyanobacterial linage". The Ecology of Cyanobacteria. Eds. Brian A. Whitton and Malcolm Potts. Dordrecht: Kluwer Academic Publishers. 13.

Sørensen, K. B., D. E. Canfield, et al. (2004). "Salinity Responses of Benthic Microbial Communities in a Solar Saltern (Eilat, Israel)." Applied and Environmental Microbiology 70(3): 1608-1616.

Stephens, D. W. and D. M. Gillespie (1976). "Phytoplankton Production in the Great Salt Lake, Utah, and a Laboratory Study of Algal Response to Enrichment " Limnology and Oceanography 21(1): 74-87.

Sturm, P. A. (1980). "The Great Salt Lake Brine System”. Great Salt Lake: A Scientific, Historical, and Economic Overview. Ed. J. W. Gwynn. Salt Lake City: Utah Geological and Mineral Survey. 147.

Utah Geological and Mineral Survey. (1990). The Great Salt Lake Information Sheet. Utah Geological Survey, Public Information Series 8:1-2.

Whitton, B. A. and M. Potts (2000). The Ecology of Cyanobacteria: Their Diversity in Time and Space. Dordrecht: Kluwer Academic Publishers.

Williams, W. D. (1998). "Salinity as a determinant of the structure of biological communities in salt lakes" Hydrobiologia 381(1-3): 191-201. 


\section{Appendix: Original and Transformed Data}

Transformed Data Aphanothece halophytica

\begin{tabular}{|c|c|c|c|c|c|c|c|c|}
\hline Medium & Inoculum & Replicate 1 & Replicate 2 & Replicate 3 & Replicate 4 & Replicate5 & Replicate 6 & Total \\
\hline \multirow[t]{4}{*}{ Rail North } & Rail North & 6 & 5 & 5 & 4 & 3 & 3 & 26 \\
\hline & Rail South & 4 & 2 & 1 & 1 & 1 & 0 & 10 \\
\hline & Antelope N & 2 & 3 & 4 & 3 & 2 & 6 & 21 \\
\hline & Antelope S & 4 & 5 & 5 & 5 & 8 & 8 & 34 \\
\hline \multirow[t]{4}{*}{ Rail South } & Rail North & 2 & 1 & 3 & 8 & 2 & 2 & 18 \\
\hline & Rail South & 2 & 5 & 1 & 3 & 5 & 3 & 20 \\
\hline & Antelope N & 2 & 4 & 3 & 1 & 4 & 4 & 18 \\
\hline & Antelope S & 2 & 0 & 0 & 0 & 1 & 0 & 3 \\
\hline \multirow[t]{4}{*}{ Antelope N } & Rail North & 2 & 0 & 0 & 2 & 2 & 3 & 9 \\
\hline & Rail South & 2 & 3 & 2 & 0 & 1 & 2 & 9 \\
\hline & Antelope N & 3 & 2 & 3 & 5 & 2 & 2 & 16 \\
\hline & Antelope S & 1 & 1 & 3 & 0 & 1 & 1 & 8 \\
\hline \multirow[t]{5}{*}{ Antelope S } & Rail North & 3 & 5 & 5 & 4 & 5 & 2 & 24 \\
\hline & Rail South & 0 & 0 & 1 & 0 & 4 & 0 & 5 \\
\hline & Antelope N & 1 & 0 & 5 & 1 & 0 & 1 & 9 \\
\hline & Antelope S & 1 & 1 & 0 & 1 & 1 & 1 & 6 \\
\hline & Total & 37 & 37 & 41 & 39 & 44 & 39 & 237 \\
\hline
\end{tabular}

\begin{tabular}{|l|l|ccccccc|r|}
\hline Medium & Inoculum & Replicate & Replicate 2 & Replicate $\mathbf{3}$ & Replicate 4 & Replicate 5 & Replicate 6 & Total \\
\hline Rail North & Rail North & 33 & 21 & 21 & 19 & 11 & 12 & $\mathbf{1 1 7}$ \\
& Rail South & 15 & 3 & 2 & 2 & 2 & 0 & $\mathbf{2 4}$ \\
& Antelope N & 3 & 11 & 18 & 10 & 6 & 36 & $\mathbf{8 4}$ \\
Rail South & Antelope S & 17 & 21 & 27 & 22 & 65 & 61 & $\mathbf{2 1 3}$ \\
& Rail North & 5 & 1 & 10 & 62 & 4 & 4 & $\mathbf{8 6}$ \\
& Rail South & 5 & 29 & 2 & 10 & 23 & 12 & $\mathbf{8 1}$ \\
& Antelope N & 3 & 16 & 9 & 1 & 18 & 15 & $\mathbf{6 2}$ \\
& Antelope S & 3 & 0 & 0 & 0 & 1 & 0 & $\mathbf{4}$ \\
Antelope N & Rail North & 3 & 0 & 0 & 3 & 6 & 9 & $\mathbf{2 1}$ \\
& Rail South & 3 & 9 & 3 & 0 & 1 & 3 & $\mathbf{1 9}$ \\
& Antelope N & 10 & 4 & 7 & 24 & 3 & 3 & $\mathbf{5 1}$ \\
& Antelope S & Antelope S & 1 & 2 & 9 & 0 & 2 & 1 & $\mathbf{1 5}$ \\
& Rail North & 11 & 28 & 22 & 14 & 21 & 5 & $\mathbf{1 0 1}$ \\
& Rail South & 0 & 0 & 1 & 0 & 15 & 0 & $\mathbf{1 6}$ \\
& Antelope N & 2 & 0 & 23 & 2 & 0 & 2 & $\mathbf{2 9}$ \\
& Antelope S & 2 & 1 & 0 & 2 & 2 & 1 & $\mathbf{8}$ \\
\cline { 2 - 8 } & Total & $\mathbf{1 1 6}$ & $\mathbf{1 4 6}$ & $\mathbf{1 5 4}$ & $\mathbf{1 7 1}$ & $\mathbf{1 8 0}$ & $\mathbf{1 6 4}$ & $\mathbf{9 3 1}$ \\
\hline
\end{tabular}




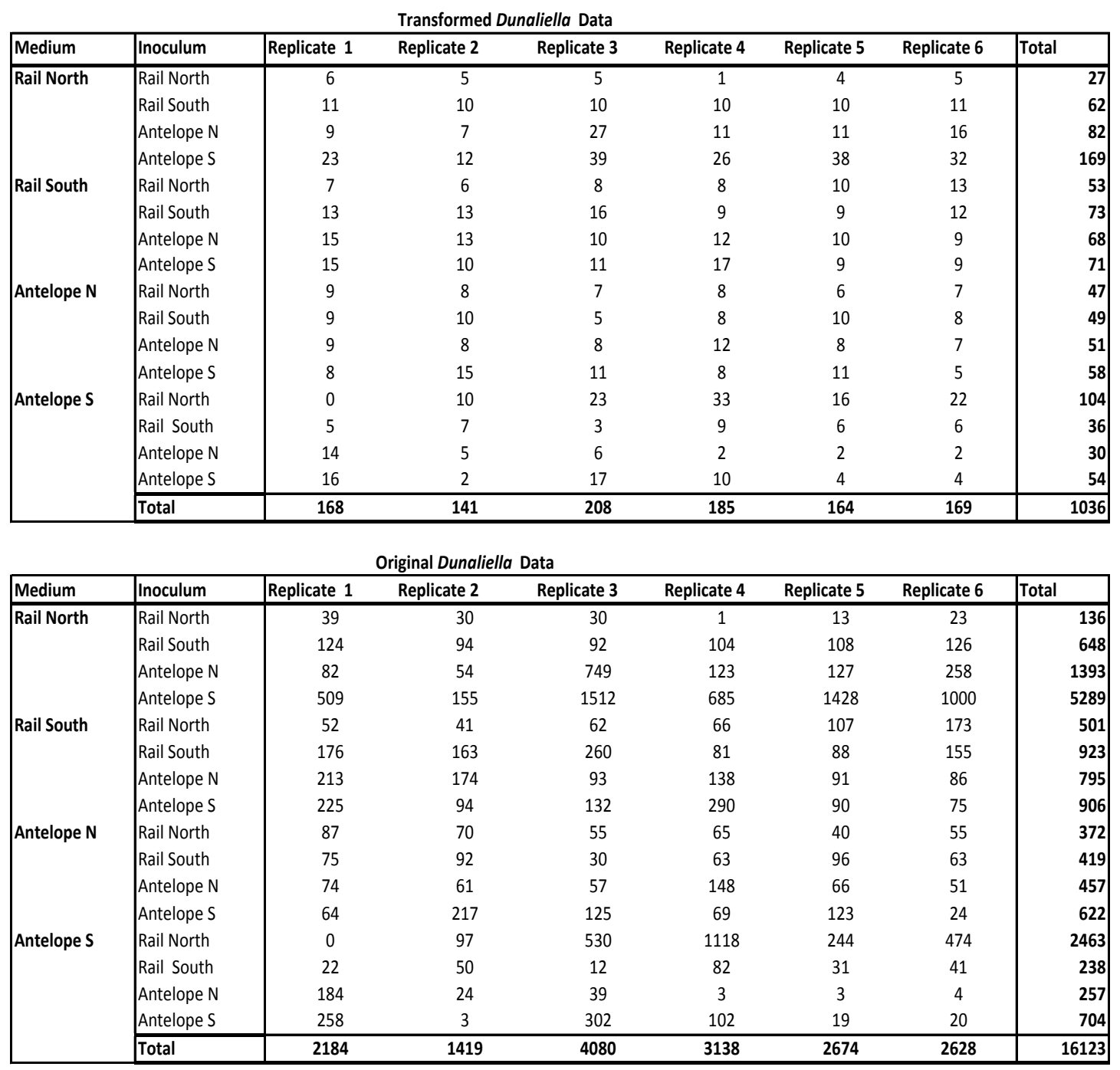

